\title{
Audit Committee: Size, Independence and Environmental Disclosure of Non-Finance Service Companies in Nigeria: The Moderating Role of Audit Committee Share Ownership
}

\author{
Buba Muhammad Mamman Agbi Eniola Samuel Joshua Okpanachi \\ Department of Accounting, Faculty of Management Sciences, \\ Nigerian Defence Academy, Kaduna, Nigeria
}

\begin{abstract}
This study examined the effect of audit committee size and audit committee independence on environmental disclosure of non-finance service companies listed in Nigeria. Extant literature on this topic is more in developed countries where legal regulatory framework exists. There are limited empirical studies in developing countries like Nigeria that examine the effect audit committee size and independence on environmental disclosure, measured with Global Reporting Initiative checklist and their results have wide variant. Secondary data were collected from the annual reports of the sampled companies. 58 companies out of the population of 89 listed nonfinancial companies in Nigeria were sampled out. Descriptive statistics and multiple regression were employed for analysis. The study finds that the direct effect of audit committee size and audit committee independence on environmental disclosure is insignificant with probability values of 0.154 and 0.107 , respectively. However, when moderated by audit committee share ownership, the effect of audit committee size on environmental disclosure of the sampled companies become significant with Probability value of 0.049 . This finding suggests that audit committee size has positive and significant effect on environmental disclosure of non-finance companies listed in Nigeria where members of audit committee has shares in the company. Based on the findings, the study recommends that regulatory authorities should encourage companies to select members of audit committee with share ownership in the companies because it influences the effect of AC size on environmental disclosure.
\end{abstract}

Keywords: Environmental disclosure, audit committee size, audit committee independence, audit committee share ownership, non-financial service companies, Nigeria

DOI: $10.7176 / \mathrm{RJFA} / 12-8-03$

Publication date: April $30^{\text {th }} 2021$

\section{Introduction}

Growing public awareness about the role of companies in environmental change has drawn the attention of many stakeholders. These concerns, put firms under intense pressure to work in an environmentally responsible ways and thus called upon to disclose information about their environmental performance (Iwata \& Okada, 2011; Ribeiro \& Aibar-Guzman, 2010). Companies are demanded to operate responsibly in order to protect the environment from the negative impact of business activities. Environmental disclosure refers to the process of communicating the environmental impacts of business activities to the various stakeholders. Environmental Disclosure also means provision of information about operational performance of companies that affect the environment, to different stakeholder groups

The need for companies to behave responsibly and accountable to the environment, necessitates governments and stock markets in both developed and developing countries to establish regulations to enhance environmental responsibility. Despite the fact in many jurisdictions companies voluntarily disclose information about the impacts of their operational activities on the environment, corporate ability to meet the information needs of various stakeholders remains questionable. The quality of environmental information disclosed is essential to enable stakeholders make accurate and reasonable evaluation of performance and take appropriate action (Global Reporting Initiative, GRI, 2013). Companies are therefore, under immense pressure to improve the quality of environmental information they disclose. The need therefore, exist to identify the factors that influence managers' decisions pertaining disclosure and to apply these factors to predict disclosure levels and improve the quality of environmental information. Rupley, Brown and Marshal (2012) stated that effective monitoring mechanisms can encourage management to act in the best interests of the various stakeholders. Good corporate governance is an effective monitoring mechanism put in place to improve transparency and accountability in information disclosure practice in companies. Audit committee is one of such monitoring mechanisms.

Audit committee (AC) is a sub-committee of the Board that specializes in, and is responsible for, ensuring the accuracy and reliability of the financial statements provided by management (Kuang, 2007). In Nigeria, section 359 (6) of the Companies and Allied Matters Acts CAMA (2020), as amended, provides that the functions of audit committee are to review the audited and unaudited financial statements as well as other special 
investigation of the company in accordance with the legal requirement and agreed ethical practices. The act also requires audit committee to ensure that the company maintains effective system of accounting and internal control as well as to review the scope and results of external auditors thereby reaffirming their objectivity.

Similarly, AC reviews risk management systems, including risk associated with corporate environmental responsibility issues, on an annual basis. AC is expected to challenge management on key sustainability and significant reporting issues such as the clarity and completeness of disclosure contained within the annual report (Smith, 2003), and evaluate how the company is incorporating them to suit its own business strategy and governance objective (KPMG, 2010). It has also been argued that effective AC is essential for corporate governance to be effective (Zaman, Hudaib \& Haniffa, 2011). Presence of AC brings accounting skills and experience to bear for corporate governance to have a positive and important influence on social and environmental disclosures.

In the same vein, $\mathrm{AC}$ is best known for error reduction and insistence for regulatory compliance and hence, enhances internal control and improves disclosure quality (Ho \& Wong, 2001). The UK Corporate Governance Code recommends that AC should consist of 6 financially literate members and at least one should be a financial expert (FRC, 2010). The financial expert is to assure quality of financial reporting and the credibility of information provided to the market (Smith, 2003). The size of audit committee and level of independence exercised by members of audit committee are factors that could influence the quality of environmental information disclosed by a company.

Significant number of research on environmental disclosure as a function of corporate governance disclosure has been conducted especially in countries where effective legal/regulatory frameworks exist (Isukul \& John, 2017). However, research on factors responsible for environmental disclosure has been few in developing countries, like Nigeria (Ndukwe, Dibial \& Onwuchekwa, 2015; Utile, Tarbo \& Ikiya, 2017; Yahaya, 2018). Again, the limited number of literature focused mainly on oil and gas companies (Ayoola \& Olasanmi, 2013). Furthermore, audit committee as one of the characteristics of corporate governance mechanisms and adduced the strongest arm calls for more research as the number of literature on it has been few. The impact of audit committee characteristics on environmental disclosure is an area that requires many studies because of the duties delegated to the committee on monitoring companies' reporting, generally.

The study examined the effect of audit committee Size and audit committee Independence on environmental disclosure of non-financial companies listed in Nigeria and to find out whether audit committee share ownership, acting as a moderator could affect the relationship among audit committee Size, audit committee Independence and the environmental disclosure.

Based on this objective, the following hypotheses are tested;

i. Ho H $_{1}$ Audit Committee Size (ACS) has no significant effect on Environmental disclosure of nonfinancial service companies listed in Nigeria;

ii. $\mathrm{Ho}_{2}$ : Audit Committee Independence (ACI) has no significant effect on Environmental disclosure of non-financial service companies listed in Nigeria;

iii. $\mathrm{Ho}_{3}$ : $\mathrm{AC}$ share ownership has no significant influence on the effect of Audit Committee on environmental disclosure of non-finance firms listed in Nigeria.

iv. $\mathrm{Ho}_{4}$ : Share ownership of members of $\mathrm{AC}$ has no significant influence on the impact of ACI on environmental disclosure of non-finance service companies listed in Nigeria

The study covers a period of ten (10) years from 2010 to 2019. It is expected that the result of this study would influence decision making by regulators and policy maker such as Federal Environmental Protection Agency (FEPA), Nigerian Stock Exchange (NSE), Security and Exchange Commission (SEC) and the Federal Ministry of Environment. Besides, the study contributes to the limited body of literature on the effect of AC size and $\mathrm{AC}$ independence on environmental disclosure and the moderating effect of share ownership of AC members on the relationship between the AC characteristics and environmental disclosure of non-financial companies listed in Nigeria.

\section{Literature Review}

Environmental disclosure which is also referred to as Corporate Environmental Reporting (Buniamin, 2010), is a means of communicating company's environmental performance. Environmental disclosure can also be explained as the process by which a company communicates information regarding the range of its environmental activities to a variety of Stakeholders including employees, local communities, shareholders, customers, government and environmental groups (Sarivudeen \& Sheham, 2013). Environmental information disclosure in Nigeria is and it means disclosures willingly made by companies in excess of regulatory requirements or free choices on the part of company managements to provide accounting and other information believed to be relevant for decision making by users of annual reports (Tashakor, 2014). Adam, Mohamed and Yunusa, (2016) preferred to explain environmental disclosure as a process of communicating environmental information about companies impact, performance and it contribution to ecologically sustainable developments, 
in view of the broad nature and scope of the concept.

Environmental disclosure is an important aspect of a company's information management for external communication and is important to company's survival as financial reporting. Many companies realize the value relevance of voluntary reporting on company business environmental performance, in addition to financial results. Various stakeholders are more and more interested in environmental disclosure in the same way shareholders are particularly interested in financial reports. An effective environmental report can help assure stakeholders of the company's strategy for continued financial success without affecting environment (Banerjee, 2002). In response to calls from various stakeholders the Nigerian Securities and Exchange Commission (NSEC) in 2011 issued a Code of Corporate Governance (CCG) for listed companies that require disclosure of information on the nature and extent of its environmental policies and practices. The Nigerian Stock Exchange Commission (SEC) followed suit by releasing Sustainability Reporting Guidelines in early 2018 mandating all companies on the stock exchange to report on its environmental activities.

Concept of Audit Committee. Audit committee serves as a monitoring mechanism that aims to improve the quality of information disclosure to the various stakeholder. Audit committee is one of the major operating committees of a company's board of directors that is in charge of overseeing financial reporting and other information disclosure. Board of directors is required to ensure and maintain good corporate governance in corporations while the various board Committees which $\mathrm{AC}$ is one of them are set up to assist the board in achieving greater efficiency in the performance of its oversight functions and strengthening governance structure. The need for Committees is premised on the fact that for the Board to concentrate its attention on more strategic issues and take informed decisions there is need to form Committees that will focus spotlights on specific matters. Thus, Principle 11 of the Nigerian Code of Corporate Governance 2018 stipulates that "to ensure efficiency and effectiveness, the Board delegates some of its functions, duties and responsibilities to wellstructured committees without abdicating its responsibilities".

By delegating tasks to Committees, Board can spend the time more efficiently on strategy. At their discretions, committees can seek independent professional advice and call for clarifications from senior management in order to enrich decision making process. Committees prepare the groundwork for decision making and report at the subsequent Board meetings.

Audit Committee Size. By Audit Committee size it means the number of members of audit committee. Nigerian Code of Corporate Governance (2018) state that each audit committee should consist of a substantial number of members relative to the board size. A larger size of audit committee generally carries more expertise and experience, and thus is able to raise more insights during meetings. Dalton, Daily, Johnson and Ellstrand (1999) found a positive relationship between size of audit committee and monitoring function, which leads to higher performance. It was argued in various literatures that if the size of a team is large, high probability exists that individual members may be infected by 'crowd effect' and be prone to follow the others' opinion without giving a deeper thought on issues. Where this happens, the audit committee members are less likely willing to query the potential errors in accounting reports during internal review process, which can create greater chance of errors passing through and be presented, subsequently (Kipkoech \& Rono, 2016). Anderson, Mansi and Reeb (2004) found out that audit committee size is negatively related to financial reporting. Carcello and Neal (2003) found no association between audit committee size and financial reporting disclosure by management

Audit Committee Independence. Audit committee independence means an AC member who has not been and is not currently employed by the company. AC independence also means an $\mathrm{AC}$ member does not do significant amount of business with the company on which he is serving as board member. According to Ayuso and Argandona (2007) the independence of the audit committee refers to "the degree to which board members (audit committee) is the subject of the current CEO or organization". Independent audit committee should assist the board fulfills its statutory and fiduciary responsibilities (Weir \& Laing, 2001). It is required that the Board appoints AC representatives and presents them to shareholders for their approval at the annual general meeting. It is required that $\mathrm{AC}$ membership be split into an equal proportion between executive and non-executive directors. The idea is to ensure the independence of the committee, thereby creating more confidence in the board activities, enhanced financial control and more credibility to the workings of the committee in monitoring company's financial reporting process (Kibiya, Che-Ahmad \& Amran, 2016). According to DeZoort, Hermanson, Archambeault and Reed (2002), an independent audit committee promotes the best interests of corporate stakeholders. Independence has been accepted as a good practice in corporate governance, but it still remains one of the most common variables in the audit committee research literature.

Literature on audit Committee size and independence, and the moderating role of AC share ownership as they affect environmental disclosure of non-finance companies listed in Nigeria, are reviewed in this section. Aburaya (2012) examined the influence of audit committee independence on environmental disclosure quantity and quality in UK using Stakeholder-agency theory to back the study. The study used content analysis on annual report of 229 companies from 2004-2007. The study employed OLS pooled regression technique to estimate the relationship between audit committee independence and environmental disclosure. It was stablished that higher 
independent directors on the audit committee influenced higher environmental disclosure quantity and quality. The study needs to be replicated in a developing country because it was conducted in a developed country with a jurisdiction distinctively different from Nigeria. Furthermore, the period covered have being overshadowed with series of economic, political and regulatory events. Finding by Aburaya (2012) is not different from the result obtained by Djuminah, Wuryani, Kurniawati, and Satyanovi (2017) who examined the effect of audit committee independence on environmental disclosure from organization theory perspective. The sample used consists of 57 Indonesia, 21 Malaysia and 18 companies in Thailand. The study found that independent audit committee has a significant positive effect on environmental disclosure. Deficiency of this study lies in the use of short of time (three years) besides the fact that there are differences in terms of environmental disclosure practices among the three countries examined and Nigeria.

Similarly, Li, Mangena and Pike (2012) investigated the relationship between audit committee characteristics and intellectual capital (IC) disclosure of 100 UK listed firms. It was found that Intellectual Capital disclosure is positively associated with audit committee size. The mere fact that the data is cross sectional and the disclosure item is intellectual capital, further evidence is needed to establish nature of the relationship between AC size and environmental disclosure. In another study, Madi (2012) examined the influence of audit committee size on corporate voluntary disclosure of 292 listed Malaysian firms. It was reported that audit committee size are significantly associated with corporate voluntary disclosure. However, finding by Mahdi (2012) differed from that of Royaie and Ebrahimi (2015) in which they examined the impact of audit committee size on voluntary ethics disclosure. It was found that AC size does not influence voluntary disclosure.

Appuhami and Tashakor (2017) in a study of 300 Australian firms examined the effects of audit committee characteristics on voluntary corporate social responsibility (CSR) and environmental disclosures. The study adopted the methods of word and sentence counts to account for environmental disclosure. The objective of the study was to assess whether AC characteristics such as size, frequency of meetings, independence, independent chair, financial expertise and gender diversity influence voluntary CSR and environmental disclosures. The study found that $\mathrm{AC}$ size has significant and positive association with environmental disclosure at $5 \%$ and $1 \%$ level for word counts and sentence, respectively. The use of word and sentence counts is a mechanistic approach which does not reveal much evidence about quality of environmental information disclosed by the firms.

Eyenubo, Mohamed and Ali (2017), examined the relationship between audit committee size and financial reporting quality in Nigeria. 189 companies were sampled and 664 years observation from the period of 20112015. They adopted panel data regression and audit committee size was found positive and significant with financial reporting quality. Their results underscore the importance of the corporate governance recommendation as a mean of strengthening the monitoring and oversight role which audit committee plays in the financial reporting process. This study is corroborated by the findings in Suarez, Garcia, Mendez and Gutierrez (2012) who found that financial reporting is significantly influenced by AC size. The weakness in both study lies in the fact that they were not about the effect of AC size on environmental disclosure.

Ofoegbu, Odoemelam, and Okafor (2018) studied the influence of audit committee independence on environmental disclosure quantity in South Africa and Nigeria. Secondary data were obtained from annual report of 213 South Africa and 90 Nigeria environmentally sensitive firms for the year 2015. Content analysis was applied on the annual report and OLS was employed as the technique of analysis. Their findings revealed that audit committee independence has no significant influence on the extent of environmental disclosure of listed companies in both countries examined. Use of cross sectional data adoption of OLS as technique of data analysis were identified as some of the weaknesses of this study. Time series effect was not considered as a factor that could alter the results.

Furthermore, Chariri, Januarti, Nur, and Yuyetta (2018) used cross sectional analysis in 2015 to examine the relationship between audit committee independence and carbon emission disclosure from agency theory perspective. The study took place in Nordic (of Scandinavia, Finland and Iceland) with sample of 105 companies. Using regression technique as tool of analysis, the study revealed that audit committee independence has a significant positive effect on carbon emission disclosure. Therefore, the study concluded that, the more independent member on the audit committee, the better the carbon emission disclosure. However, the study suffered some deficiencies as cross sectional data which does not cater for time effect was used instead of panel data. The finding of this study sharply differed from a research by Appuhami and Tashakor (2017) in which 300 Australian listed firms were examined to find out whether or not audit committee characteristics have significant effect on voluntary corporate social responsibility (CSR) and environmental disclosures. Appuhami and Tashakor (2017) revealed that AC independence has no significant effect on environmental disclosure in Australian companies.

Moreso, Naseer and Rashid (2018) studied the relationship between audit committee independence and environmental reporting in Pakistan. Content analysis was used on 50 non-financial companies listed on Pakistan Stock Exchange for the year 2014-2015. The result showed that independence of audit committee has a 
significant positive influence on the level of environmental reporting in Pakistan. The study period is two years which is considered to be short. The study could be improved upon by increasing the number of period covered. In same vein, Sheikh, Abdullah and Shah (2019) examined the effect of characteristics of audit committee on voluntary disclosure level in Pakistan using 150 firms. The results suggest that AC size and AC independence have statistically significant effect on voluntary disclosure while, other independent variables do not have any significant effect. Although the study is about effect of Audit Committee characteristics, the dependent variable (voluntary disclosure) differs from environmental disclosure, being the focus of this research.

\section{Methodology}

The population of the study consist of all the eighty-nine non-financial companies listed on the Nigerian Stock Exchange from January 2010 to December 2019. The firms comprise of twenty-seven consumer goods firms, twenty industrial goods firms, eleven health care firms, six conglomerates firms, five agricultural firms and twenty natural resources firms. Out of 89 non-finance companies listed in Nigeria from 2010 to 2019,58 firms were sampled due to availability of data. 41 companies were filtered out based on unavailability of their annual reports for extraction of data, for reasons ranging from delisting, technical suspension, and lack of trading during the period of the study, as shown below in Table 1 .

\section{Table 1}

Population and sample size frame

\begin{tabular}{llll}
\hline S/N & Sector & Population & Sample \\
\hline 1 & Consumer goods & 27 & 15 \\
2 & Industrial goods & 20 & 13 \\
3 & Health care & 11 & 6 \\
4 & Conglomerate & 6 & 5 \\
5 & Agriculture & 5 & 4 \\
6 & Natural resources & 20 & 15 \\
& Total & 89 & 58
\end{tabular}

Source: Field work (2020)

The choice of these sectors is influenced by the nature of their industrial production activities which are considered to be environmentally sensitive and prone to cause pollution Uyagu, Okpanachi, Nyor and Muhammad (2017).

\section{TABLE 2}

Variable definition and measurement

\begin{tabular}{lll}
\hline Variable & Variable Measurement & Sources \\
\hline Dependent Variable (DV) & & Daizy \& Das (2014); Abusufian \\
& & $\begin{array}{l}\text { Measured as an index that indicates } \\
\text { (2012); Jurica, Lady and Prillia }\end{array}$ \\
$\begin{array}{l}\text { Global Environmental Index from Global Reporting } \\
\text { Initiative (GRI) }\end{array}$ & $\begin{array}{l}\text { Total items disclosed in GRI } \\
\text { components }\end{array}$ & $\begin{array}{l}\text { (2012) Umulkher and Muganda } \\
\text { (2017); Carroll (1991). }\end{array}$
\end{tabular}

Independent variables(IV)

Audit Committee Size (SZ)

Audit committee
Independence (IND)

Audit committee Share ownership (SO)

Firm Size (FS) Source: Field work (2020)

The following models were used to examine the hypotheses of the study.

i. $\quad \mathrm{GRI}_{\text {it }}=\beta_{0}+\beta_{1} \mathrm{SZ}_{\text {it }}+\beta_{2} \mathrm{IND}_{\text {it }}+\mathrm{e}_{\text {it }}$.

ii. $\quad \mathrm{GRI}_{\mathrm{it}}=\beta_{0}+\beta_{1} \mathrm{SZ}_{\mathrm{it}}+\beta_{2} \mathrm{IND}_{\text {it }}+\beta_{3} \mathrm{FS}_{\mathrm{it}}+\mathrm{e}_{\mathrm{it}}$.
Appuhami and Tashakor (2017); Madi (2012); Madi, et al, (2014); Li, Number of Audit committee et al (2012); Buallay and AlDhaen members (2018); Bicer and Feneir, 2019;

Ratio of independent audit Chariri, et al (2018); Appuhami and committee members to the total Tashakor (2017); Al-Shaer (2013); number of audit committee Madi, et al (2014); Li. Et al (2012); members

This was measured by the Kusnadi, Eong, Suwardy, and Wang percentage of shares owned by (2016) members of audit committee

This is proxied using the natural Yahaya and Andow logarithm of total assets of the firm Habbash(2 016)

(2015), 
iii. $\quad \mathrm{GRI}_{\mathrm{it}}=\beta_{0}+\beta_{1} \mathrm{SZ}_{\mathrm{it}}+\beta_{2} \mathrm{IND}_{\text {it }}+\beta_{3} \mathrm{SZ}_{\text {it }} * \mathrm{SO}_{\text {it }}+\beta_{4} \mathrm{IND}_{\text {it }} * \mathrm{SO}_{\text {it }}+\mathrm{e}_{\mathrm{it}}$

iv. $\quad \mathrm{GRI}_{\text {it }}=\beta_{0}+\beta_{1} \mathrm{SZ}_{\text {it }}+\beta_{2} \mathrm{IND}_{\text {it }}+\beta_{3} \mathrm{SZ}_{\mathrm{it}} * \mathrm{SO}_{\mathrm{it}}+\beta_{4} \mathrm{IND}_{\text {it }} * \mathrm{SO}_{\text {it }}+\beta_{5} \mathrm{FS}_{\mathrm{it}}+\mathrm{e}_{\mathrm{it}}$.

Where:

GRI = Quality of environmental disclosure measure using 'Global Reporting Initiative'

$\mathrm{B}_{0} \quad=$ Intercept

$\mathrm{B}_{1-2}=$ Coefficients of independent variables

$\mathrm{SZ} \quad=$ AC Size

$\mathrm{IND}=\mathrm{AC}$ Independence

SO = AC Share Ownership

FS $=$ Firm Size

e $\quad=$ Stochastic error term or disturbance term.

The data used in this study were collected from secondary sources. The data in respect of all the variables of the study was extracted from the annual reports and accounts of the sampled non- financial service companies quoted on the floor of Nigeria Stock Exchange. The study used Global Reporting Initiative (GRI) with a checklist of 34 items, to account for environmental disclosure. Several studies have used GRI as a fore-runner for environmental disclosure and many other sustainable reporting (Daizy \& Das, 2014). This gave reason for GRI to be adopted for this study. The dichotomous measurement approach was used to score the disclosed items in order to ensure that all items are adequately represented and free from subjectivity and bias; items not disclosed are scored 0 , while items disclosed are scored 1 . Finally, the total items disclosed is divided by total possible items as identified by the checklist.

For the purpose of this research, the multiple regression analysis was employed to determine whether audit committee size and audit committee independence significantly affect environmental disclosure of non-financial service companies listed in Nigeria within the period of this study. Similarly, multiple regression analysis was used to determine whether audit committee share ownership affect the relationship among audit committee size and independence and environmental disclosure of non-financial companies listed in Nigeria. Fixed Effect (FE) and Random Effect (RE) regression models was employed alongside the pooled Ordinary Least Squares (OLS) regression. The FE regression model concentrates on differences within individual company. The parametric assumptions about coefficient on the other hand, will impose that a change in explanatory variable has the same effect, whether it is a change from one period to the other or a change from one individual company to the another (Verbeek 2000). This means that, the effect of changes in explanatory variables will be the same for all units and all periods, but that the average level for one country may be different from that of another country. The intercept thus, captures the effects of those variables that will be peculiar to a country and expected to be constant overtime. The analysis was conducted using Statistics/Data Analysis Software (STATA 16).

\section{Data Presentation and Analysis}

This section presents the data and discusses the results of the analyses and interpretations. The descriptive statistics and other univariate test results are first presented and interpreted. Thereafter, the results of the panel data analyses, as well as those of correlation matrices and diagnostic tests are presented and interpreted as well. Inferences derivable from these results, as reflected in the reviewed literature, are discussed after the tests of the hypotheses earlier formulated by the study. The section concludes with highlights of the policy implications emanating from the findings.

Table 3

Descriptive Statistics

\begin{tabular}{llrrrr}
\hline Variable & Obs & Mean & \multicolumn{1}{c}{ Std. Dev. } & Min & \multicolumn{1}{c}{ Max } \\
\hline GRI & 580 & .011 & .031 & 0.000 & 0.147 \\
SZ & 560 & 5.516 & 1.025 & 2.000 & 9.000 \\
IND & 560 & .461 & 0.125 & 0.000 & 1.000 \\
SO & 560 & 1.286 & 3.500 & 0.000 & 35.862 \\
FS & 560 & 7.176 & 0.925 & 4.992 & 9.231 \\
\hline
\end{tabular}

Source: STATA 16 Outputs

Table 3 shows that environmental disclosure is a ratio where its value falls from 0 and 1 and it could also be expressed in percentage. Table 3 shows that the mean environmental disclosure is $1.1 \%$ with standard deviation of $3.1 \%$ while minimum and maximum value is $0 \%$ and $14.71 \%$, respectively. $1.1 \%$ average value indicates that average environmental disclosure quality over the period under investigation is considered relatively low. This may be as a result of companies not disclosing many aspects of their business operations to reduce the environmental impact. High deviation from mean is as a result of variation in the environmental information made available.

From Table 3, Audit Committee Size (SZ) has mean value of 5.52 and standard deviation of 1.03 with 
minimum and maximum value of 2 and 9 respectively. The wide dispersion of the standard deviation from mean shows that the number of audit committee members varies from company to company. The minimum value of 2 shows that some companies are not complying with the provisions of Company and Allied Matters Act. Similarly, the AC independence (IND) is measured as ratio of independent non-executive members to total members on the committee. Table 3 also shows the average of AC independence across the sampled firms is $46.1 \%$ and the standard deviation is $12.5 \%$. The standard deviation of $12.5 \%$ is far from the mean value of $46.1 \%$ indicating divergence of the values of independence among the studied firms over the period of study. The minimum value of $0 \%$ shows the presence of companies with no independent non-executive directors on the committee while the maximum value of $100 \%$ indicates that in some companies all members of Audit Committee are independent non-executive directors.

Furthermore, Table 3 shows the average Share Ownership to be 1.29 and the standard deviation to be 3.50 with minimum and maximum values of 0.00 and 35.86, respectively. The wide range of dispersion is due to the difference in the involvement of the audit committee members in owning shares, among the listed companies. Table above shows the average Firm size of the sampled companies in Nigeria to be approximately 7 with standard deviation of 0.93 with minimum and maximum value of approximately 5 and 9 respectively.

\section{Diagnostic Tests}

This section presents the results from the diagnostic tests conducted, to maintain the un-biasness of the parameters. The diagnostic tests include: Normality test, serial correlation test, multicolinearity test, heteroscedasticity test and hausman specification test. In addition, the Shapiro-Wilk test for data normality was conducted and the result presented in Table 5, below. Under Shapiro-Wilk test for normal data, null hypothesis principle was used to check if the variables come from a normally distributed population $\left(\mathrm{H}_{0}\right.$ : the data is normally distributed).

Table 4

Data Normality Test

\begin{tabular}{lrrrrr}
\hline Variable & Obs & \multicolumn{1}{c}{ W } & \multicolumn{1}{c}{ V } & \multicolumn{1}{c}{ Z } & \multicolumn{2}{c}{ Prob>z } \\
\hline GRI & 580 & 0.8685 & 50.560 & 9.539 & 0.000 \\
SZ & 580 & 0.972 & 10.949 & 5.791 & 0.000 \\
IND & 580 & 0.890 & 42.239 & 9.058 & 0.000 \\
SO & 580 & 0.440 & 215.25 & 12.999 & 0.000 \\
FS & 580 & 0.984 & 6.054 & 4.357 & 0.000 \\
\hline
\end{tabular}

Source: STATA 14 Outputs

The results on Table 4 shows that the data does not follow normal distribution, this is due to the fact that the $\mathrm{P}$-values of the Z-statistics are statistically significant at $99 \%$ confidence interval (1\% level of significance). The normality assumption failure of the data means that the models require a more generalized estimator as suggested by Guassian theorem (1929) which say that the problem of normality in a data will not affect the Best Linear Unbiased Estimators (BLUE).

\subsection{Serial Correlation Test Result}

Serial correlation test was conducted to find out if there exist serial correlation problem in the study and the result presented in Table 5.

Table 5

Serial correlation

\begin{tabular}{lcr}
\hline Model & F-Value & Probability \\
\hline Model 1 & 580.601 & 0.000 \\
Model 2 & 586.693 & 0.000 \\
Model 3 & 408.261 & 0.000 \\
Model 4 & 415.287 & 0.000 \\
\hline
\end{tabular}

Source: STATA 16 Outputs

The above result on Table 5 shows that all the 4 models suffer from serial correlation problem with probability value of 0.000 , respectively. This also implies that the result considers the robust fixed and random effect as most appropriate estimator for analysis.

\section{Test for Multicolinearity}

The Variance Inflation Factor (VIF) test was also conducted to ascertain the presence of multicollinearity problem among the explanatory variables and the result presented in Tale 6 . 
Table 6

Test for multicolinearity

\begin{tabular}{llr}
\hline Variable & VIF & 1/VIF \\
\hline SZ & 1.61 & 0.621 \\
IND & 1.00 & 1.000 \\
FS & 1.61 & 0.621 \\
\hline
\end{tabular}

\section{Source: STATA 16 Outputs}

Decision rule

$\mathrm{VIF}=1($ Not correlated $)$

$1<$ VIF $<10$ (Moderately correlated)

VIF $>=10$ (Highly correlated) (By Stephanie, 2015)

Variance inflation factors (VIF) measures how much the variance of the estimated regression coefficients is inflated as compared to when the predictor variables are not linearly related. The results from the Table 6 show that the variables do not have multicollinearity problem (no correlation between predictors) since the VIF's are less than 5. The tolerance level in the above table is also within the acceptable range of 1 . This shows that the independent variables are appropriate and well fit into the models. As shown in Table 6, since none of the VIF value reached a value of 5, there is no problem of multicollinearity among the included variables in the model thus we maintained the two variables for the purpose of estimation.

\section{Test for Heteroskedasticity}

Heteroscedasticity is used to test the normality of residuals. Cameron and Trivedi decomposition of IM-test for Heteroskedasticity was used to test the existence of Heteroskedasticity. Heteroskedasticity check, necessitated the running of fixed and random effect models for the study is as presented in Table 7.

Table 7

Test for Heteroscedascity (Cameron \& Trivedi's decomposition of IM-test)

\begin{tabular}{lcc}
\hline Model & chi $^{\mathbf{2}} \mathbf{( 1 )}$ & ${\text { Prob }>\mathbf{c h i}^{\mathbf{2}}}$ \\
\hline Model 1 & 22.72 & 0.000 \\
Model 2 & 88.77 & 0.000 \\
Model 3 & 58.22 & 0.000 \\
Model 4 & 143.77 & 0.000 \\
\hline
\end{tabular}

Source: STATA 16 Outputs

The result on Table 7 tests the null hypothesis that the error variances are all equal versus the alternative that the error variances are a multiplicative function of one or more variables. The result show that all the 4 models are not free from Heteroskedasticity and their variance are not equal (not Homoscedastic) with P-value as 0.000 , respectively, which are less than 0.05 at $95 \%$ confidence interval for rejecting the null hypothesis of Homoskedasticity. Therefore, this study conclude that all the models are Heteroskedastic. The Breusch Pagan Lagrangian Multiplier test for random effects tests for null hypothesis is, there is no panel effect (i.e. the variance of the random effect is zero) while its alternative hypothesis is that there is panel effect (i.e. the variance of the random effect is not equal to zero. The results are displayed on Table 8.

Table 8

Breusch and Pagan Lagrangian multiplier test for random effects

\begin{tabular}{lrr}
\hline Model & chi $^{\mathbf{2}}$ & Prob $^{\mathbf{c}} \mathbf{c h i}^{\mathbf{2}}$ \\
\hline Model 1 & 1770.83 & 0.000 \\
Model 2 & 1723.89 & 0.000 \\
Model 3 & 1658.92 & 0.000 \\
Model 4 & 1652.85 & 0.000 \\
\hline Sour
\end{tabular}

Source: STATA 16 Outputs

As shown on Table 8, the 4 models suffers from panel effect with the P-values of 0.000 , less than 0.05 level of significant at $95 \%$ confidence interval, for accepting the null hypothesis of no panel effect. Therefore, we conclude that there are panel effects among the models. We therefore proceed to run Hausman Test.

\section{Hausman Specification Test Result}

Hausman Specification Test specifies the actual model that best explains the study. It helps to specify if a random effect model or a fixed effect model is to be run with its probability value. Hausman Specification Test null hypothesis is that the preferred model is random effect; the alternate hypothesis is that the preferred model is fixed effects. If the P-value is less than 0.05, then we do not accept the null hypothesis and conclude that the preferred model is the fixed effect model. However, if the P-value is greater than 0.05 at $95 \%$ confidence interval, we do not reject the null hypothesis and conclude that the preferred model is the random effect model. 
Table 9

Hausman specification test

\begin{tabular}{lrr}
\hline Model & chi $^{\mathbf{2}}$ & Prob $^{>} \mathbf{c h i}^{\mathbf{2}}$ \\
\hline Model 1 & $\mathbf{1 . 7 7}$ & $\mathbf{0 . 4 1 2}$ \\
Model 2 & $\mathbf{2 . 6 8}$ & $\mathbf{0 . 4 4 3}$ \\
Model 3 & $\mathbf{5 . 8 2}$ & $\mathbf{0 . 2 1 3}$ \\
Model 4 & 3.69 & $\mathbf{0 . 5 9 5}$
\end{tabular}

Source: STATA 16 Outputs

From Table 9, Hausman specification test result show that 4 model are not significant with probability value of $0.412,0.443,0.213$ and 0.595 respectively, which implies that a random effect model will be run for the 4 models.

\section{Multiple Regression Result}

This section presents the regression results of the dependent variables namely; Environmental disclosure measured with Global Reporting Initiative, two independent variables; Audit Committee size (SZ) and Audit Committee Independence, one moderating variable; Share Ownership (SO) and one control variable namely; Firm size (FS).

Table 10

Regression Result

\begin{tabular}{|c|c|c|c|c|c|c|}
\hline GRI & Coef. & Std. Err. & $\mathbf{Z}$ & $\mathbf{P}>\mathbf{Z}$ & \multicolumn{2}{|c|}{ [95\% Conf. Interval] } \\
\hline $\mathrm{SZ}$ & .004571 & .0023947 & 1.91 & 0.056 & -.0001225 & .0092646 \\
\hline IND & .0239015 & .0142252 & 1.68 & 0.093 & -.0039794 & .0517823 \\
\hline _cons & -.0248724 & .0174293 & -1.43 & 0.154 & -.0590331 & .0092883 \\
\hline Wald chi2(2) & 4.00 & & & & & \\
\hline Prob $>$ chi 2 & 0.1353 & & & & & \\
\hline R-sq: & 0.0846 & & & & & \\
\hline
\end{tabular}

Source: STATA 16 Outputs

The result of the regression analysis for Model 1 revealed that the R-squared, often referred to as coefficient of determination of the variables, for model 1 is 0.0846 , as shown on Table 10 . This implies that $8.5 \%$ of the changes in environmental disclosure (GRI) is explained by the independent variables (Audit Committee size and Audit Committee Independence). This is also confirmed by the Wald Chi-Squared statistics of 4.00 whose probability (0.1353) implies that the independent variables combined are not good predictor of environmental information (they are statistically not significant). A unit change in audit committee size will increase GRI by 0.005 , though it is statistically not significant with probability 0.056 which is greater than 0.05 significant level at $95 \%$ confidence interval for rejecting the null hypothesis of no significant effect. Also, a unit change in audit committee independence will increase GRI by 0.024 , and it is also not statistically significant with probability 0.093 which is greater than 0.05 at $95 \%$ confidence interval for rejecting the null hypothesis of no statistically significant effect. The study contradicts the findings of Chariri, Januarti, Nur, and Yuyetta (2018) that revealed AC independence has significant effect on environmental disclosure and which was corroborated by Naseer and Rashid (2018)

Table 11

Regression results

\begin{tabular}{|c|c|c|c|c|c|c|}
\hline GRI & Coef. & Std. Err. & $\mathbf{Z}$ & $\mathbf{P}>\mathbf{Z}$ & {$[95 \%$ Conf. Ir } & val] \\
\hline SZ & .0034832 & .0024454 & 1.42 & 0.154 & -.0013097 & .0082761 \\
\hline IND & .0221601 & .0137523 & 1.61 & 0.107 & -.004794 & .0491141 \\
\hline FS & .0101367 & .0042923 & 2.36 & 0.018 & .0017239 & .0185495 \\
\hline cons & -.0908142 & .0355917 & -2.55 & 0.011 & -.1605726 & -.0210558 \\
\hline Wald chi2(2) & 10.07 & & & & & \\
\hline Prob $>$ chi 2 & 0.0180 & & & & & \\
\hline R-sq: & 0.1311 & & & & & \\
\hline
\end{tabular}

Source: STATA 16 Outputs

Table 11 also reveals that the R-squared for model 2 was found to be 0.131 . This implies that $13.1 \%$ of the changes in GRI can be explained by the independent variable combined (Audit Committee size and Audit Committee Independence and the control variable, Firm size). This is also confirmed by the Wald Chi-Squared statistics of 10.07 whose probability (0.0180), which implies that the independent variables combined, are good predictor of GRI. A unit change in audit committee size will increase GRI by 0.003 , though it is statistically not 
significant with probability 0.154 which is greater than 0.05 for rejecting the null hypothesis of no significant effect. Also, a unit change in audit committee independence will increase GRI by 0.022 , which it is statistically also not significant with probability 0.107 . While the introduced control variable (Firm Size) shows a positive and significant effect on GRI with probability value of 0.018 this is in agreement with the results obtained by Burgwal and Vieira (2014).

Table 12

Regression results

\begin{tabular}{|c|c|c|c|c|c|c|}
\hline GRI & Coef. & Std. Err. & $\mathbf{Z}$ & $\mathbf{P}>\mathbf{Z}$ & \multicolumn{2}{|c|}{ [95\% Conf. Interval] } \\
\hline SZ & .0046 & .0023 & 1.97 & 0.049 & .0000149 & .009198 \\
\hline IND & .0221 & .0139 & 1.59 & 0.112 & -.0051893 & .0494308 \\
\hline $\operatorname{lnSZSO}$ & -.0015 & .0027 & -0.54 & 0.591 & -.0068105 & .0038767 \\
\hline INDSO & .0028 & .0024 & 1.13 & 0.257 & -.0020165 & .0075478 \\
\hline cons & -.0213 & .0171 & -1.25 & 0.212 & -.0548667 & .0121793 \\
\hline Wald chi2(2) & 5.52 & & & & & \\
\hline Prob $>$ chi 2 & 0.2378 & & & & & \\
\hline R-sq: & 0.0799 & & & & & \\
\hline
\end{tabular}

Source: STATA 16 Outputs

Similarly, Table 12 also shows that the R-squared for model 3 was found to be 0.080 . This implies that $8 \%$ of the changes in GRI can be explained by the independent variables with aid of the moderating variable, AC share ownership. The results of Model 3 as shown on table 13 indicate, a unit change in audit committee size will increase GRI by 0.005 . With probability 0.049 which is less than 0.05 significant level at $95 \%$ confidence interval (for not accepting the null hypothesis of no significant effect). This implies that audit committee size has significant effect on environmental disclosure measured by GRI. The finding corroborates the result found by Madi (2012) and Appuhami and Tashakor (2017) in which AC size was found to have significant positive effect, while AC independent does not have significant effect on environmental disclosure. However, the result differs from Royaie and Ebrahimi (2015) who found that AC size has no significant effect on voluntary disclosure. Also, a unit change in audit committee independence will increase GRI by 0.022 and it is statistically not significant with probability 0.112 which is greater than 0.05 significant level at $95 \%$ confidence interval for not rejecting the null hypothesis. Here, the introduction of the moderator (SO) account for an additional $1 \%$ change in the R-squared (SO account for almost $1 \%$ additional changes in GRI). The introduction of the moderator (AC Share Ownership) also influence the performance of AC size on GRI to be statistically significant.

Table 13

Regression results

\begin{tabular}{|c|c|c|c|c|c|c|}
\hline GRI & Coef. & Std. Err. & $\mathbf{z}$ & $\mathbf{P}>\mathbf{Z}$ & \multicolumn{2}{|c|}{ [95\% Conf. Interval] } \\
\hline SZ & .0034 & .0024 & 1.45 & 0.147 & -.001209 & .0080941 \\
\hline IND & .0205 & .0135 & 1.51 & 0.131 & -.0060758 & .0470003 \\
\hline $\operatorname{lnSZSO}$ & -.0008 & .0027 & -0.29 & 0.775 & -.0059891 & .0044666 \\
\hline INDSO & .0021 & .0024 & 0.89 & 0.374 & -.0025539 & .0067968 \\
\hline FS & .0103 & .0042 & 2.45 & 0.014 & .0020783 & .0186173 \\
\hline cons & -.0890 & .0349 & -2.55 & 0.011 & -.15747 & -.0204887 \\
\hline Wald chi2(2) & 11.94 & & & & & \\
\hline Prob $>$ chi2 & 0.036 & & & & & \\
\hline R-sq: & 0.121 & & & & & \\
\hline
\end{tabular}

Source: STATA 16 Outputs

Similarly, the results of model 4 on Table 13 reveal that the R-squared was found to be 0.121 . This implies that $12.13 \%$ of the changes in GRI is explained by Audit Committee size and Audit Committee Independence, Firm Size (as control variable) and the influence of AC Share Ownership, as a moderator. This is also confirmed by the Wald Chi-Squared statistics of 11.94 whose probability $(0.0356)$ implies that the independent variables combined are better predictors of GRI. A unit change in AC size will increase GRI by 0.003 , though it is statistically not significant with probability 0.147 , for rejecting the null hypothesis of no significant effect. This result contradicts that found by Sheikh, Abdullah and Shah (2019 on AC size, which revealed significant effect. Also, a unit change in audit committee independence will increase GRI by 0.022 and it is statistically significant with probability 0.131 which is greater than 0.05 significant level at $95 \%$ confidence interval for rejecting the null hypothesis. This is similar to the findings of Ofoegbu, Odoemelam, and Okafor (2018) and Sheikh, Abdullah and Shah (2019) on AC independence but differs from Aburaya (2012). The control variable (Firm Size) shows a positive effect (0.009) on GRI and it is statistically significant with probability value of 0.014 . The results also indicate that introduction of the moderator Share Ownership (SO) does not influence the relationship between independent variables in this model and environmental disclosure, represented by GRI. 


\section{Summary, Conclusion, and Recommendations.}

The research hypotheses are to test whether or not Audit Committee size and Audit Committee Independence have significant effect on Environmental disclosure of listed non-financial companies in Nigeria. Similarly, AC share ownership was introduced to find out whether or not it significantly influences the effect of independent AC size and independence on environmental disclosure. The result shows that audit committee size and audit committee independence have no significant effect on environmental disclosure without the AC share ownership, as a moderator.

However, when AC share ownership was introduced as a moderator, it influenced AC size to significantly affect environmental disclosure. Although, introduction of Share Ownership as a good moderator influenced the effect AC size on environmental disclosure. The study recommends that regulatory authorities should encourage companies to select members of audit committee with share ownership in the companies because it influences the effect of $\mathrm{AC}$ size on environmental disclosure.

\section{References}

Abernathy, J. L., Beyer, B., Masli, A., \& Stefaniak, C. (2014). The association between characteristics of audit committee accounting experts, audit committee chairs, and financial reporting timeliness. Advances in Accounting, Incorporating Advances in International Accounting, 30(2), 283-297.

Aburaya, R. K. (2012). Corporate governance and environmental disclosure: UK Evidence. PhD Thesis submitted at Durham University.

Adam, N. C., Mohamed, R., \& Yunusa, N. (2016). Executive and non-executive auditors and environmental disclosure among listed firms in Nigeria. Journal of Advanced Research in Business and Management Studies, 5(1), 1-7

Anderson, R. C., Mansi, S. A., \& Reeb, D. M. (2004). Board characteristics, accounting report integrity, and the cost of debt. Journal of accounting and economics, 37(3), 315-342

Appuhami, R. \& Tashakor, S. (2017). The Impact of audit committee characteristics on CSR Disclosure: An Analysis of Australian Firms. Australian Accounting Review.

Ayoola, T. J. \& Olasanmi, O. (2013). Business case for integrated reporting in the Nigerian oil and gas sector. Issues in Social and Environmental Accounting, 7(1), 30-5.

Ayuso, S. \& Argondona, A. (2007). Responsible Corporate Governance: Towards a Stakeholder Board of Directors? http://www.iese.edu/research/pdfs/DI-0701-E.pdf (application/pdf)

Bassey, B. E., Effiok, S. O., \& Eton, O. E. (2013). The impact of environmental accounting and reporting on organizational performance of selected oil and gas companies in Niger Delta Region of Nigeria. Research Journal of Finance and Accounting, 4(3).

Buniamin, S. (2010). The quantity and quality of environmental reporting in annual report of public listed companies in Malaysia. Issues in Social and Environmental Accounting, 4(2), 115-135

Burgwal, D. V. \& Viera, R. J. O. (2014). Disclosure determinants in Dutch listed companies. https://doi.org/10.1590/S1519-70772014000100006.

Carcello, J. V. \& Neal, T. L. (2003). Audit committee characteristics and auditor dismissals following "new" going-concern reports. The Accounting Review 78 (1), 95-117

Chariri, A., Januarti, I. \& Yuyetta, E. N. A., (2018) Audit committee characteristics and carbon emission disclosure. E3S Web of Conferences 73,ICENIS.

Daizy \& Das, N. (2014). Sustainability reporting framework: comparative analysis of global reporting initiatives and Dow Jones sustainability index. International Journal of Science, Environment and Technology, 3(1), $55-66$

Dalton, D. R., Daily, C. M., Johnson, J.L., \& Ellstrand, A.E. (1999). Number of directors and financial performance: a meta-analysis. Academy of Management Journal, 42, 674-686.

DeZoort, F., Hermanson, D., \& Houston, R. (2003). Audit committee member support for proposed audit adjustments: a source credibility perspective. Auditing. Journal of Practice \& Theory, 22(2), 189-205.

Djuminah, Wuryani, M., Kurniawati, S. B., \& Satyanovi, V. A. (2017). Firms characteristics and environmental disclosure : a comparative study of hospitality industry of Indonesia, Malaysia and Thailand. Review of Integrative Business and Economics Research, 6(4), 364-376.

Eyenubi, S. A., Mohamed, M. \& Ali, M. I. (2017). ). An empirical analysis on the financial reporting quality of the quoted firms in Nigeria: Does audit committee size matter? International Journal of Academic Research in Business and Social Sciences 7( 9).

García - Sánchez, I. M., Frias - Aceituno, J.V. \& Garcia - Rubio, R., (2012). Determining factors of audit committee attributes: Evidence from Spain. International Journal of Auditing, 16(2).184-3.

Global Reporting Initiative (GRI). (2013). G4 sustainability reporting: reporting principles and standard disclosures. www.globalreporting.org/resourcelibrary/GRIG4-Part1-Reporting-Principles-and-StandardDisclosures. 
Ho, S. S. M. \& Wong, K. S. (2001). A study of the relationship between corporate governance structure and the extent of voluntary disclosure. Journal of International Accounting, Auditing and Taxation, 10(2): 139-156

Fakhari, H. \& Pitenoei, Y. Z. (2017). The impact of audit committee and its characteristics on the firms' information environment. Iranian Journal of Management Studies (IJMS) 10(3), 577-608

Isukul, A. C. \& John, J.C. (2017). Corporate governance disclosure in developing countries: a comparative analysis in Nigerian and South African banks. SAGE Open 1-17

Iwata, H. \& Okada, K. (2011). How does environmental performance affect financial performance? Evidence from Japanese manufacturing firms. Ecological Economics, 70(9), 1691-1700.

Kibiya, M. U. Che-Ahmad, A. \& Amran, N. A. (2016). Audit committee independence, financial expertise, share ownership and financial reporting quality: Further evidence from Nigeria. International Journal of Economics and Financial Issues, 6(7).

Kipkoech, S. R. \& Rono, L. (2016). Audit committee size, experience and firm financial performance. Evidence from Nairobi Securities Exchange, Kenya. Research Journal of Finance and Accounting, 7(15).

Kokabi, S., Kordlouie, H., \& Mirabi, V. R. (2015). The impact of function efficiency of internal audit and the audit committee on financial restatements of firms. Journal of Accounting knowledge and Management Auditing, 4(16), 27-34.

KPMG. (2017). The KPMG survey of Corporate responsibility Reporting, 2017. Retrieved from https://assets.kpmg.com/content/dam/kpmg/xx/pdf/2017/10/kpmg-survey-of-corporate-responsibilityreporting-2017.

Kuang, C. (2007). Audit committee characteristics and earnings management. A dissertation submitted to Auckland University of Technology, New Zealand

Lehn, K. M., Patro, S. \& Zhao, M. (2009). Determinants of the size and composition of US corporate boards: 1935-2000. Financial Management 38(4): 747-780

Li, J., Mangena, M. \& Pike, R. (2012). The effect of audit committee characteristics on intellectual capital disclosure. The British Accounting Review 44 (2012) 98-110

Madi, H. K. (2012). Audit committee effectiveness and voluntary disclosure in Malaysia: pre and post introduction of the revised Malaysian code on corporate governance 2007. Thesis for Doctor of Business Administration Universiti Utara Malaysia October 2012

Naseer, M., \& Rashid, K. (2018). The Relationship between environmental reporting and corporate governance: Empirical evidence from Pakistan. Open Source Books.

Ndukwe, O., Dibia, N.O., \& Onwuchekwa, C. J. (2015). Determinants of environmental disclosures in Nigeria: A case study of oil and gas companies. International Journal of Finance and Accounting, 4(3): 145-152.

Ofoegbu, G. N., Odoemelam, N., \& Okafor, R. G. (2018). Corporate board characteristics and environmental disclosure quantity : Evidence from South Africa (integrated reporting ) and Nigeria (traditional reporting). Cogent Business \& Management, 5(1), 1-27. https://doi.org/10.1080/23311975.2018.1551510

Ribeiro, V., \& Aibar-Guzman, C. (2010). Determinants of environmental accounting practices in local entities: evidence from Portugal. Social Responsibility Journal, 6(3), 404-419.

Royaie, R. A. \& Ebrahimi, M. (2015). The effects of audit committee characteristics on voluntary ethics disclosure. Quarterly Financial Accounting Journal, 7(25), 71-88.

Rupley, K. H., Brown, D. \& Marshall, R. S. (2012). Governance, media and the quality of environmental disclosure. J. Account. Public Policy 3(1) 610-640.

Sarivudeen, A. L., \& Sheham, A. M. (2013). Corporate governance practices and environmental reporting: A study of selected listed companies in Sri Lanka. Proceedings of the Third International Symposium, 6-6.

Sheikh, R. A. G., Abdullah \& Shah M. H. (2019). Impact of audit committee characteristics on voluntary disclosures: Evidence from Pakistan. Asian Online Journal Publishing Group

Suarez, J. A., Garcia, E. C., Mendez, C. F. \& Gutirrez, C. R. (2012). The effectiveness of the audit committee in Spain: implications of its existence on the auditor's opinion. This article is published with open access at SpringerLink.com.

Tashakor, S. (2014). The influence of audit committee characteristics on voluntary corporate social responsibility disclosure: Australian evidence. Thesis for Degree of Masters of Research Macquarie University Sydney, Australia.

Utile, B. J., Tarbo, D. I., \& Ikya, E. A. (2017). Corporate environmental reporting and the financial performance of listed manufacturing firms in Nigeria. International Journal of Advanced Academic Research Social and Management Sciences, 3(8), 15 - 25

Uyagu, B. D., Okpanachi, J., Nyor, T., \& Muhammad, L. M. (2017). Effect of firm characteristics on environmental reporting practices of listed manufacturing firms in Nigeria. Nigerian Journal of Management Sciences, 6(1), 139-148.

Weir C. \& Laing, D. (2001). Governance structures, director independence and corporate performance in the UK. European Business Review 13(2):86-95 
Yahaya, O. A. (2018). Environmental reporting practices and financial performance of listed environmentallysensitive firms in Nigeria. Savanna: A Journal of Environmental and Social Sciences, 24(2), 403-412.

Zaman, M., Hudaib, M. \& Haniffa, B. (2011). Corporate governance quality, audit fees and non-audit services fees. Journal of Business Finance \& Accounting, 38(1) \& (2), 165-197.

Appendix

$\begin{aligned} / & /\end{aligned}$

Single-user 2-core Stata network license expires 20 Aug 2022:

Serial number: 501609213901

Licensed to: DOWNLOADLY.IR 085227746673

WwW.DownLoadLy.iR 085227746673

Notes:

1. Unicode is supported; see help unicode_advice.

2. More than 2 billion observations are allowed; see help obs advice.

3. Maximum number of variables is set to 5000; see help set maxvar.

- import excel "C:\Users\Neville lamar\Downloads \Mr Kolawole Data.xlsx", sheet("

> Sheet2") firstrow

(10 vars, 620 obs)

. sum GEI SZ IND SO FS

\begin{tabular}{r|rrrrr} 
Variable & Obs & Mean & Std. Dev. & Min & Max \\
\hline GEI & 580 & .0113562 & .0309535 & 0 & .1471 \\
SZ & 580 & 5.515517 & 1.025462 & 2 & 9 \\
IND & 580 & .4609346 & .1252448 & 0 & 1 \\
SO & 580 & 1.286125 & 3.500245 & 0 & 35.86237 \\
FS & 580 & 7.176371 & .9248718 & 4.9916 & 9.231
\end{tabular}

- reg GEI SZ IND

\begin{tabular}{|c|c|c|c|c|c|c|}
\hline Source & SS & $d f$ & MS & Number of obs & $=$ & 580 \\
\hline & & 2 & & Proh & - & a \\
\hline Residual & .511048425 & 577 & .000885699 & $\mathrm{R}$-squared & $=$ & 0.0788 \\
\hline Total & .554749388 & 579 & .000958116 & $\begin{array}{l}\text { Adj R-squared } \\
\text { Root MSE }\end{array}$ & $\begin{array}{l}= \\
=\end{array}$ & $\begin{array}{r}0.0756 \\
.02976\end{array}$ \\
\hline
\end{tabular}

\begin{tabular}{r|rrrrrr}
\hline GEI & Coef. & Std. Err. & $t$ & $\mathrm{P}>|\mathrm{t}|$ & {$[95 \%$ Conf. } & Interval] \\
\hline SZ & .0063441 & .0012061 & 5.26 & 0.000 & .0039751 & .008713 \\
IND & .0463451 & .0098754 & 4.69 & 0.000 & .0269489 & .0657412 \\
_cons & -.0449966 & .0081813 & -5.50 & 0.000 & -.0610653 & -.0289279 \\
\hline
\end{tabular}


. vif

\begin{tabular}{r|rr} 
Variable & VIF & $1 /$ VIF \\
\hline IND & 1.00 & 0.999949 \\
SZ & 1.00 & 0.999949 \\
\hline Mean VIF & 1.00 &
\end{tabular}

- imtest, white

White's test for Ho: homoskedasticity against $\mathrm{Ha}$ : unrestricted heteroskedasticity

$\begin{array}{ll}\operatorname{chi}(5) & =22.72\end{array}$

Prob $>$ chi2 $=0.0004$

Cameron \& Trivedi's decomposition of IM-test

\begin{tabular}{r|ccc}
\hline Source & chi2 & df & p \\
\hline Heteroskedasticity & 22.72 & 5 & 0.0004 \\
Skewness & 51.48 & 2 & 0.0000 \\
Kurtosis & 24.38 & 1 & 0.0000 \\
\hline Total & 98.58 & 8 & 0.0000 \\
\hline
\end{tabular}

- ovtest

Ramsey RESET test using powers of the fitted values of GEI Ho: model has no omitted variables

$$
\begin{aligned}
F(3,574)= & 6.66 \\
\text { Prob }>F= & 0.0002
\end{aligned}
$$


- xtset id Years

panel variable: id (unbalanced)

time variable: Years, 2010 to 2019

delta: 1 unit

- xtreg GEI SZ IND

Random-effects GLS regression

Group variable: id

Number of obs $=580$

$\mathrm{R}-\mathrm{sq}$ :

within $=0.0734$

between $=0.0846$

Number of groups =

overall $=0.0767$

Obs per group:

$\begin{array}{rr}\min = & 10 \\ \operatorname{avg}= & 10.0 \\ \max = & 10\end{array}$

$\operatorname{corr}\left(u_{-} i, X\right)=0$ (assumed)

Wald $\operatorname{chi2}(2)=45.20$

Prob $>$ chi2 $=0.0000$

\begin{tabular}{r|rrrrrr}
\hline GEI & Coef. & Std. Err. & z & P > |z| & [95\% Conf. Interval] \\
\hline SZ & .004571 & .0009299 & 4.92 & 0.000 & .0027484 & .0063936 \\
IND & .0239015 & .005392 & 4.43 & 0.000 & .0133334 & .0344695 \\
_cons & -.0248724 & .006712 & -3.71 & 0.000 & -.0380277 & -.0117171 \\
\hline sigma_u & .02756407 & & & & \\
sigma_e & .01222286 & & & & \\
rho & .8356773 & (fraction of variance due to u_i) &
\end{tabular}


- xttesto

Breusch and Pagan Lagrangian multiplier test for random effects

$$
G E I[i d, t]=X b+u[i d]+e[i d, t]
$$

Estimated results:

\begin{tabular}{r|cc} 
& Var & sd $=$ sqrt $($ Var $)$ \\
\hline GEI & .0009581 & .0309535 \\
$\mathrm{e}$ & .0001494 & .0122229 \\
$\mathrm{u}$ & .0007598 & .0275641
\end{tabular}

Test: $\quad \operatorname{Var}(\mathrm{u})=0$

$\underline{\operatorname{chibar2}(01)}=1770.83$

Prob $>$ chibar $2=0.0000$

- xtreg GEI SZ IND, fe

Fixed-effects (within) regression Group variable: id

R-sq:

within $=0.0734$

between $=0.0845$

overall $=0.0767$

$\operatorname{corr}\left(u_{-} i, X b\right)=0.1155$
Number of obs=

Number of groups =

Obs per group:

$\begin{array}{lr}\min = & 10 \\ \operatorname{avg}= & 10.0 \\ \max = & 10\end{array}$

$F(2,520)$

$=20.60$

Prob > F
20.60

\begin{tabular}{r|rlrrrr}
\hline GEI & Coef. & Std. Err. & $t$ & $\mathrm{P}>|\mathrm{t}|$ & [95\% Conf. Interval] \\
\hline SZ & .0044477 & .0009541 & 4.66 & 0.000 & .0025733 & .006322 \\
IND & .0231367 & .0054343 & 4.26 & 0.000 & .0124608 & .0338126 \\
_cons & -.0238394 & .0057757 & -4.13 & 0.000 & -.035186 & -.0124928 \\
\hline sigma_u & .02779614 & & & & \\
sigma_e & .01222286 & & & & \\
rho & .83796695 & (fraction of variance due to u_i) & \\
\hline
\end{tabular}

$F$ test that all u_i=0: $F(57,520)=50.89$

- est store fe 
- xtreg GEI SZ IND, re

Random-effects GLS regression

Number of obs=

580

Group variable: id

Number of groups =

R-sq:

within $=0.0734$

Obs per group:

between $=0.0846$

$\min =$

overall $=0.0767$

$\operatorname{avg}=$

10.0

$\max =$

$\operatorname{corr}\left(u_{-} i, X\right)=0$ (assumed)

Wald chi2(2)

45.20

Prob > chi2

0.0000

\begin{tabular}{r|rrrrrr}
\hline GEI & Coef. & Std. Err. & z & P $>|z|$ & [95\% Conf. Interval] \\
\hline SZ & .004571 & .0009299 & 4.92 & 0.000 & .0027484 & .0063936 \\
IND & .0239015 & .005392 & 4.43 & 0.000 & .0133334 & .0344695 \\
_cons & -.0248724 & .006712 & -3.71 & 0.000 & -.0380277 & -.0117171 \\
\hline sigma_u & .02756407 & & & & \\
sigma_e & .01222286 & & & & \\
rho & .8356773 & (fraction of variance due to u_i) & \\
\hline
\end{tabular}

- est store re

- hausman fe re

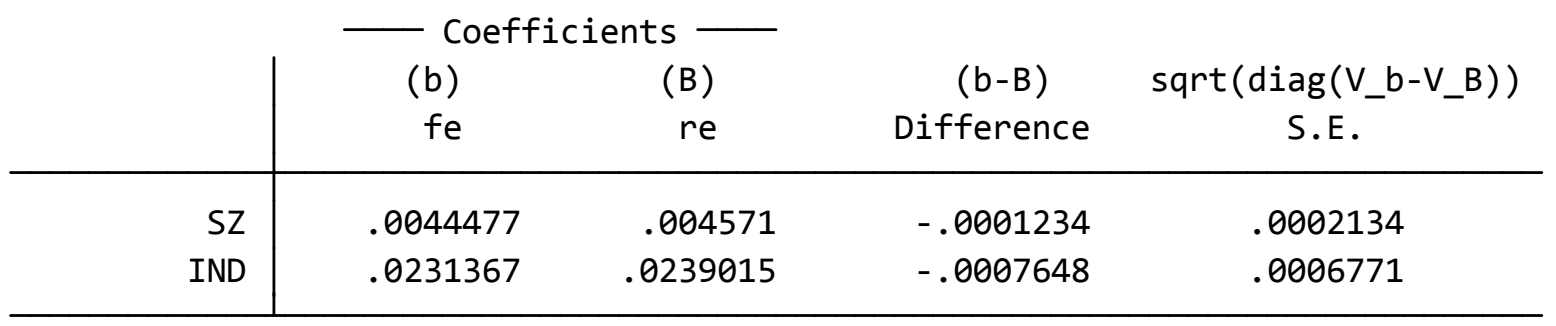

$\mathrm{b}=$ consistent under $\mathrm{Ho}$ and $\mathrm{Ha}$; obtained from xtreg $\mathrm{B}=$ inconsistent under $\mathrm{Ha}$, efficient under $\mathrm{Ho}$; obtained from xtreg

Test: Ho: difference in coefficients not systematic

$$
\begin{aligned}
& \operatorname{chi2}(2)=(b-B)^{\prime}\left[\left(V_{-} b-V_{-} B\right)^{\wedge}(-1)\right](b-B) \\
& =\quad 1.77 \\
& \text { Prob }>\text { chi2 }=0.4121
\end{aligned}
$$


- xtreg GEI SZ IND, robust re (40 missing values generated)

Random-effects GLS regression Group variable: id

Number of obs=

580

Number of groups $=\quad 58$

R-sq:

within $=0.0734$

Obs per group:

between $=0.0846$

$\min =$

overall $=0.0767$

$\operatorname{avg}=10.0$

$\max =10$

$\operatorname{corr}\left(u_{-} i, X\right)=0$ (assumed)

Wald $\operatorname{chi2}(2)=4.00$

Prob > chi2 $=0.1353$

(Std. Err. adjusted for 58 clusters in id)

\begin{tabular}{r|rlrrrr}
\hline & \multicolumn{7}{|c}{ Robust } \\
GEI & Coef. & Std. Err. & $z$ & P $>|z|$ & [95\% Conf. Interval] \\
\hline SZ & .004571 & .0023947 & 1.91 & 0.056 & -.0001225 & .0092646 \\
IND & .0239015 & .0142252 & 1.68 & 0.093 & -.0039794 & .0517823 \\
_cons & -.0248724 & .0174293 & -1.43 & 0.154 & -.0590331 & .0092883 \\
\hline sigma_u & .02756407 & & & & \\
sigma_e & .01222286 & & & & \\
rho & .8356773 & (fraction of variance due to u_i) & \\
\hline
\end{tabular}

- reg GEI SZ IND FS

\begin{tabular}{|c|c|c|c|c|c|c|}
\hline Source & SS & $d f$ & MS & Number of obs & $=$ & 580 \\
\hline Model & .078390685 & 3 & .026130228 & Prob > F & $=$ & 0.0000 \\
\hline Residual & .476358702 & 576 & .000827012 & R-squared & $=$ & 0.1413 \\
\hline Total & .554749388 & 579 & .000958116 & Root MSE & $=$ & .02876 \\
\hline
\end{tabular}

\begin{tabular}{r|rrrrrr}
\hline GEI & Coef. & Std. Err. & $t$ & $\mathrm{P}\rangle|\mathrm{t}|$ & {$[95 \%$ Conf. } & Interval] \\
\hline SZ & .0004413 & .0014795 & 0.30 & 0.766 & -.0024646 & .0033472 \\
IND & .0452973 & .009544 & 4.75 & 0.000 & .026552 & .0640426 \\
FS & .0106246 & .0016405 & 6.48 & 0.000 & .0074026 & .0138467 \\
_Cons & -.0882032 & .0103443 & -8.53 & 0.000 & -.0085202 & -.0678861 \\
\hline
\end{tabular}

. vif 


\begin{tabular}{r|rr}
\hline Variable & VIF & $1 /$ VIF \\
\hline FS & 1.61 & 0.620485 \\
SZ & 1.61 & 0.620504 \\
IND & 1.00 & 0.999662 \\
\hline Mean VIF & 1.41 &
\end{tabular}

- ovtest

Ramsey RESET test using powers of the fitted values of GEI Ho: model has no omitted variables

$$
\begin{aligned}
F(3,573)= & 12.11 \\
\text { Prob }>F= & 0.0000
\end{aligned}
$$

. imtest, white

White's test for Ho: homoskedasticity

against Ha: unrestricted heteroskedasticity

$$
\begin{array}{llr}
\operatorname{chi2}(9) & = & 88.77 \\
\text { Prob }>\text { chi2 } & = & 0.0000
\end{array}
$$

Cameron \& Trivedi's decomposition of IM-test

\begin{tabular}{r|rrc}
\hline Source & chi2 & df & $p$ \\
\hline Heteroskedasticity & 88.77 & 9 & 0.0000 \\
Skewness & 80.76 & 3 & 0.0000 \\
Kurtosis & 26.72 & 1 & 0.0000 \\
\hline Total & 196.25 & 13 & 0.0000 \\
\hline
\end{tabular}

- xtreg GEI SZ IND FS 


\section{Random-effects GLS regression \\ Group variable: id}

R-sq:

$$
\begin{aligned}
& \text { within }=0.0959 \\
& \text { between }=0.1311 \\
& \text { overall }=0.1255
\end{aligned}
$$

$\operatorname{corr}\left(u_{-} i, X\right)=0$ (assumed)
Number of obs=

Number of groups = 580

58

Obs per group:

$\begin{array}{rr}\min = & 10 \\ \operatorname{avg}= & 10.0 \\ \max = & 10\end{array}$

Wald chi2(3)

63.41

Prob > chi2

0.0000

\begin{tabular}{r|rrrrrr}
\hline GEI & Coef. & Std. Err. & $z$ & $P>|z|$ & [95\% Conf. Interval] \\
\hline SZ & .0034832 & .0009558 & 3.64 & 0.000 & .0016098 & .0053565 \\
IND & .0221601 & .0053459 & 4.15 & 0.000 & .0116822 & .0326379 \\
FS & .0101367 & .0024598 & 4.12 & 0.000 & .0053156 & .0149578 \\
_cons & -.0908142 & .0172954 & -5.25 & 0.000 & -.01247126 & -.0569159 \\
\hline sigma_u & .02665647 & & & & & \\
sigma_e & .01208392 & & & & & \\
rho & .82953191 & (fraction of variance due to u_i)
\end{tabular}

\section{- xttesto}

Breusch and Pagan Lagrangian multiplier test for random effects

$$
\operatorname{GEI}[i d, t]=X b+u[i d]+e[i d, t]
$$

Estimated results:

\begin{tabular}{r|rc} 
& Var & sd $=\operatorname{sqrt}($ Var $)$ \\
\hline GEI & .0009581 & .0309535 \\
$\mathrm{e}$ & .000146 & .0120839 \\
$\mathrm{u}$ & .0007106 & .0266565
\end{tabular}

Test: $\quad \operatorname{Var}(\mathrm{u})=0$

$$
\text { chibar2(01) }=1723.89
$$

Prob $>$ chibar $2=0.0000$


- xtreg GEI SZ IND FS, fe

Fixed-effects (within) regression Group variable: id

$\mathrm{R}-\mathrm{Sq}$ :

$$
\begin{aligned}
& \text { within }=0.0961 \\
& \text { between }=0.1293 \\
& \text { overall }=0.1238
\end{aligned}
$$

$\operatorname{corr}\left(u_{-} i, X b\right)=-0.0837$
Number of obs= Number of groups $=$ 580 58

Obs per group:

$\begin{array}{rr}\min = & 10 \\ \operatorname{avg}= & 10.0 \\ \max = & 10\end{array}$

$F(3,519)$

Prob > F
18.39

$=$

0.0000

\begin{tabular}{r|rrrrrr}
\hline GEI & Coef. & Std. Err. & $t$ & $\mathrm{P}\rangle|\mathrm{t}|$ & [95\% Conf. Interval] \\
\hline SZ & .0036342 & .0009698 & 3.75 & 0.000 & .001729 & .0055394 \\
IND & .0210913 & .0054024 & 3.90 & 0.000 & .0104781 & .0317044 \\
FS & .011042 & .0030594 & 3.61 & 0.000 & .0050318 & .0170523 \\
_cons & -.0976517 & .021233 & -4.60 & 0.000 & -.1393648 & -.0559385 \\
Sigma_u & .02692289 & & & & \\
Sigma_e & .01208392 & & & & \\
rho & .8323261 & (fraction of variance due to u_i) &
\end{tabular}

$F$ test that all $u_{-} i=0: F(57,519)=48.13$

Prob > F $=0.0000$

- est store fe

- xtreg GEI SZ IND FS, re

Random-effects GLS regression Group variable: id

R-sq:

within $=0.0959$

between $=0.1311$

overall $=0.1255$
Number of obs=

Number of groups $=$

Obs per group:

$\begin{array}{rr}\min = & 10 \\ \operatorname{avg}= & 10.0 \\ \max = & 10\end{array}$

Wald chi2(3)

$=$

$\operatorname{corr}\left(u_{-} i, X\right)=0$ (assumed)
Prob > chi2
63.41

580

0.0000

\begin{tabular}{r|rrrrrr}
\hline GEI & Coef. & Std. Err. & $z$ & $P>|z|$ & [95\% Conf. Interval] \\
\hline SZ & .0034832 & .0009558 & 3.64 & 0.000 & .0016098 & .0053565 \\
IND & .0221601 & .0053459 & 4.15 & 0.000 & .0116822 & .0326379 \\
FS & .0101367 & .0024598 & 4.12 & 0.000 & .0053156 & .0149578 \\
_cons & -.0908142 & .0172954 & -5.25 & 0.000 & -.1247126 & -.0569159 \\
Sigma_u & .02665647 & & & & & \\
Sigma_e & .01208392 & & & & \\
rho & .82953191 & (fraction of variance due to u_i)
\end{tabular}


- est store re

- hausman fe re

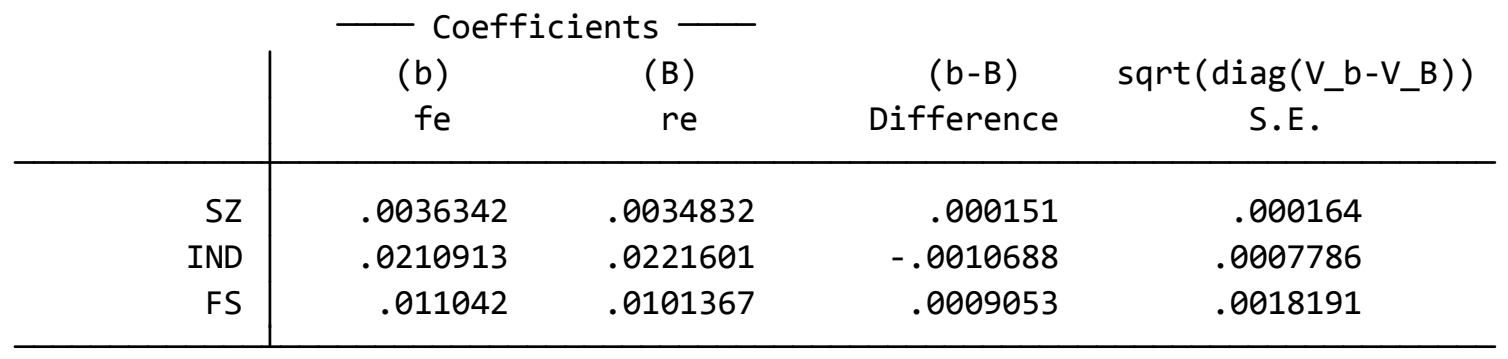

$\mathrm{b}=$ consistent under $\mathrm{Ho}$ and $\mathrm{Ha}$; obtained from xtreg $B=$ inconsistent under $\mathrm{Ha}$, efficient under Ho; obtained from xtreg

Test: Ho: difference in coefficients not systematic

$$
\begin{aligned}
\operatorname{chi} 2(3) & = & (b-B)^{\prime}\left[\left(V_{-} b-V_{-} B\right)^{\wedge}(-1)\right](b-B) \\
& = & 2.68 \\
\text { Prob }>\text { chi2 } & = & 0.4428
\end{aligned}
$$

- xtreg GEI SZ IND FS, robust re (40 missing values generated)

Random-effects GLS regression Group variable: id

R-sq:

within $=0.0959$

Number of groups =

between $=0.1311$

Obs per group:

overall $=0.1255$

$\begin{array}{lr}\min = & 10 \\ \operatorname{avg}= & 10.0 \\ \max = & 10\end{array}$

$\operatorname{corr}\left(u_{-} i, X\right)=\theta$ (assumed)

Wald $\operatorname{chi2}(3)=10.07$

(Std. Err. adjusted for 58 clusters in id)

\begin{tabular}{r|rlrrrr}
\hline \multirow{2}{*}{ GEI } & Coef. & Std. Err. & $z$ & $P>|z|$ & [95\% Conf. Interval] \\
\hline SZ & .0034832 & .0024454 & 1.42 & 0.154 & -.0013097 & .0082761 \\
IND & .0221601 & .0137523 & 1.61 & 0.107 & -.004794 & .0491141 \\
FS & .0101367 & .0042923 & 2.36 & 0.018 & .0017239 & .0185495 \\
_cons & -.0908142 & .0355917 & -2.55 & 0.011 & -.0005726 & -.0210558 \\
\hline Sigma_u & .02665647 & & & & \\
sigma_e & .01208392 & & & & \\
rho & .82953191 & (fraction of variance due to u_i) &
\end{tabular}

- gen $\mathrm{SZSO}=\mathrm{SZ} * \mathrm{SO}$ 
- reg GEI SZ IND InSZSO INDSO

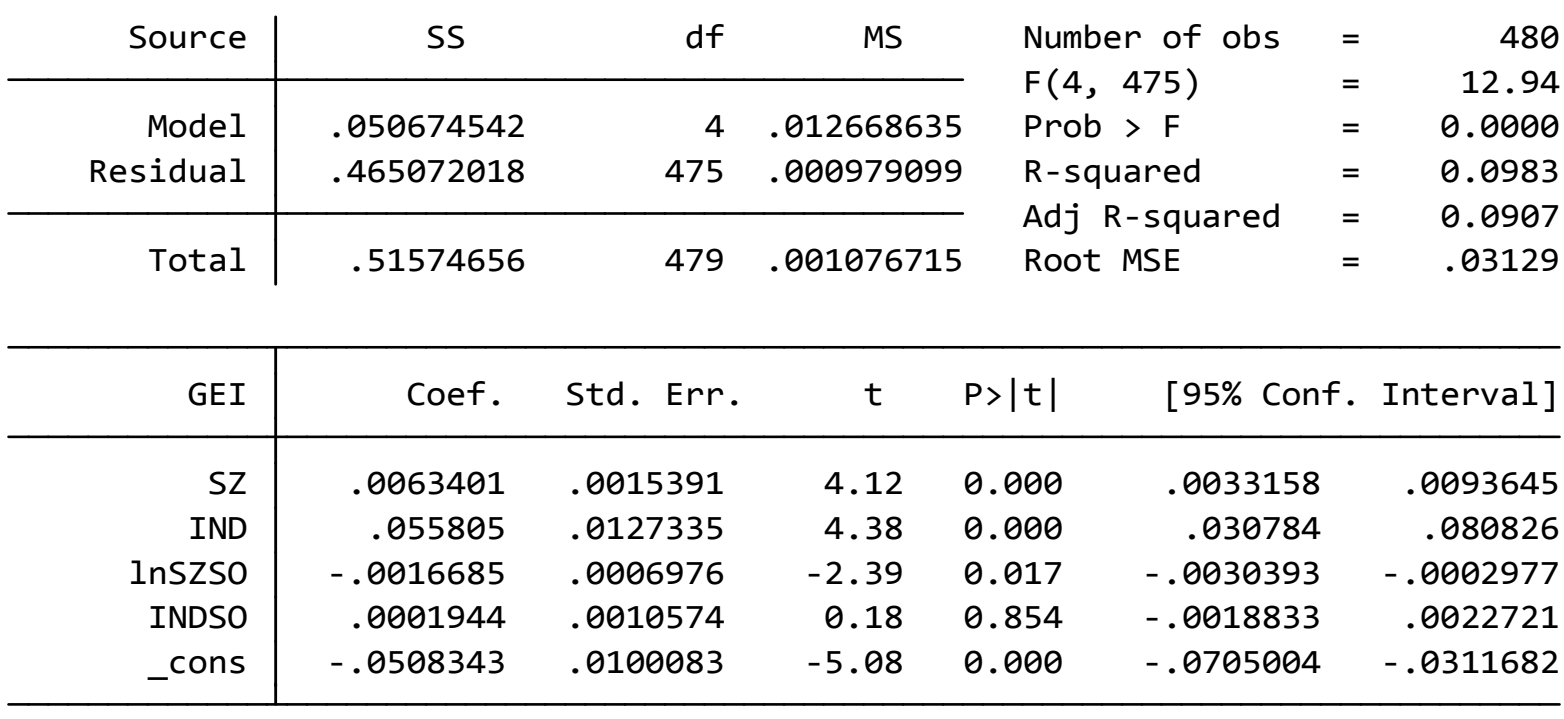

. vif

\begin{tabular}{r|rr} 
Variable & VIF & $1 / \mathrm{VIF}$ \\
\hline INDSO & 1.74 & 0.573155 \\
InSZSO & 1.73 & 0.578171 \\
SZ & 1.04 & 0.963973 \\
IND & 1.02 & 0.977218 \\
\hline Mean VIF & 1.38 &
\end{tabular}

- imtest, white

White's test for Ho: homoskedasticity against $\mathrm{Ha}$ : unrestricted heteroskedasticity
chi2(14)
47.58
Prob $>$ chi2 $=$
0.0000

Cameron \& Trivedi's decomposition of IM-test

\begin{tabular}{r|rrc}
\hline Source & chi2 & df & p \\
\hline Heteroskedasticity & 47.58 & 14 & 0.0000 \\
Skewness & 73.98 & 4 & 0.0000 \\
Kurtosis & 27.71 & 1 & 0.0000 \\
\hline Total & 149.26 & 19 & 0.0000 \\
\hline
\end{tabular}


. ovtest

Ramsey RESET test using powers of the fitted values of GEI

Ho: model has no omitted variables

$$
\begin{aligned}
F(3,472)= & 4.73 \\
\text { Prob }>F= & 0.0029
\end{aligned}
$$

- xtreg GEI SZ IND InSZSO INDSO

Random-effects GLS regression

Group variable: id

R-sq:

within $=0.0922$

between $=0.0824$

overall $=0.0716$

$\operatorname{corr}\left(u_{-} i, X\right)=0$ (assumed)
Number of obs=

Number of groups $=$

Obs per group:

$\begin{array}{rr}\min = & 2 \\ \operatorname{avg}= & 8.9 \\ \max = & 10\end{array}$

Wald chi2(4)

$=$

46.63

Prob > chi2

\begin{tabular}{r|rrrrrr}
\hline GEI & Coef. & Std. Err. & $z$ & $P>|z|$ & [95\% Conf. Interval] \\
\hline SZ & .0050886 & .0011545 & 4.41 & 0.000 & .0028258 & .0073514 \\
IND & .0296869 & .0072467 & 4.10 & 0.000 & .0154836 & .0438902 \\
InSZSO & .000164 & .0005609 & 0.29 & 0.770 & -.0009353 & .0012634 \\
INDSO & .0002435 & .0006339 & 0.38 & 0.701 & -.000999 & .001486 \\
_cons & -.0311481 & .0078429 & -3.97 & 0.000 & -.0465199 & -.0157764 \\
\hline sigma_u & .02795161 & & & & & \\
sigma_e & .01308046 & & & & & \\
rho & .82034856 & (fraction of variance due to u_i) &
\end{tabular}


- xttesto

Breusch and Pagan Lagrangian multiplier test for random effects

$$
\begin{aligned}
& \mathrm{GEI}[\mathrm{id}, \mathrm{t}]=\mathrm{Xb}+\mathrm{u}[\mathrm{id}]+\mathrm{e}[\mathrm{id}, \mathrm{t}] \\
& \text { Estimated results: }
\end{aligned}
$$

\begin{tabular}{r|cc} 
& Var & sd $=\operatorname{sqrt}($ Var $)$ \\
\hline GEI & .0010767 & .0328133 \\
$\mathrm{e}$ & .0001711 & .0130805 \\
$\mathrm{u}$ & .0007813 & .0279516
\end{tabular}

Test: $\quad \operatorname{Var}(\mathrm{u})=0$

$\underline{\operatorname{chibar2}(01)}=1497.80$

Prob > chibar $2=0.0000$

- xtreg GEI SZ IND InSZSO INDSO, fe

Fixed-effects (within) regression

Group variable: id

R-sq:

within $=0.0927$

between $=0.0688$

overall $=0.0622$

$\operatorname{corr}\left(u_{-} i, \mathrm{Xb}\right)=0.0761$
Number of obs=

Number of groups =

480

54

Obs per group:

$\begin{array}{rr}\min = & 2 \\ \operatorname{avg}= & 8.9 \\ \max = & 10\end{array}$

$\mathrm{F}(4,422)$

Prob > F
10.78

$=$

0.0000

\begin{tabular}{r|rlrrrr}
\hline GEI & Coef. & Std. Err. & $t$ & $\mathrm{P}>|\mathrm{t}|$ & [95\% Conf. Interval] \\
\hline SZ & .0048624 & .0011954 & 4.07 & 0.000 & .0025127 & .0072122 \\
IND & .0284034 & .0073476 & 3.87 & 0.000 & .013961 & .0428457 \\
InSZSO & .0003948 & .0005866 & 0.67 & 0.501 & -.0007583 & .0015479 \\
INDSO & .0002302 & .0006461 & 0.36 & 0.722 & -.0010397 & .0015002 \\
_cons & -.028743 & .0070892 & -4.05 & 0.000 & -.0426776 & -.0148083 \\
\hline sigma_u & .02818484 & & & & & \\
sigma_e & .01308046 & & & & \\
rho & .82278475 & (fraction of variance due to u_i) &
\end{tabular}

$F$ test that all $u_{-} i=0: F(53,422)=43.32$

Prob > $F=0.0000$ 
. est store fe

- xtreg GEI SZ IND InSZSO INDSO, re

Random-effects GLS regression Group variable: id

R-sq:

$$
\begin{aligned}
& \text { within }=0.0922 \\
& \text { between }=0.0824 \\
& \text { overall }=0.0716
\end{aligned}
$$

$\operatorname{corr}\left(u_{-} i, X\right)=\theta$ (assumed)
Number of obs=

Number of groups =

480

54

Obs per group:

$\begin{array}{lr}\min = & 2 \\ \operatorname{avg}= & 8.9 \\ \max = & 10\end{array}$

Wald chi2(4)

$=$

46.63

Prob > chi2

0.0000

\begin{tabular}{r|rlrrrr}
\hline GEI & Coef. & Std. Err. & $z$ & P $>|z|$ & [95\% Conf. Interval] \\
\hline SZ & .0050886 & .0011545 & 4.41 & 0.000 & .0028258 & .0073514 \\
IND & .0296869 & .0072467 & 4.10 & 0.000 & .0154836 & .0438902 \\
InSZSO & .000164 & .0005609 & 0.29 & 0.770 & -.0009353 & .0012634 \\
INDSO & .0002435 & .0006339 & 0.38 & 0.701 & -.000999 & .001486 \\
_cons & -.0311481 & .0078429 & -3.97 & 0.000 & -.0465199 & -.0157764 \\
\hline Sigma_u & .02795161 & & & & \\
sigma_e & .01308046 & & & & \\
rho & .82034856 & (fraction of variance due to u_i)
\end{tabular}

- est store re 
- hausman fe re

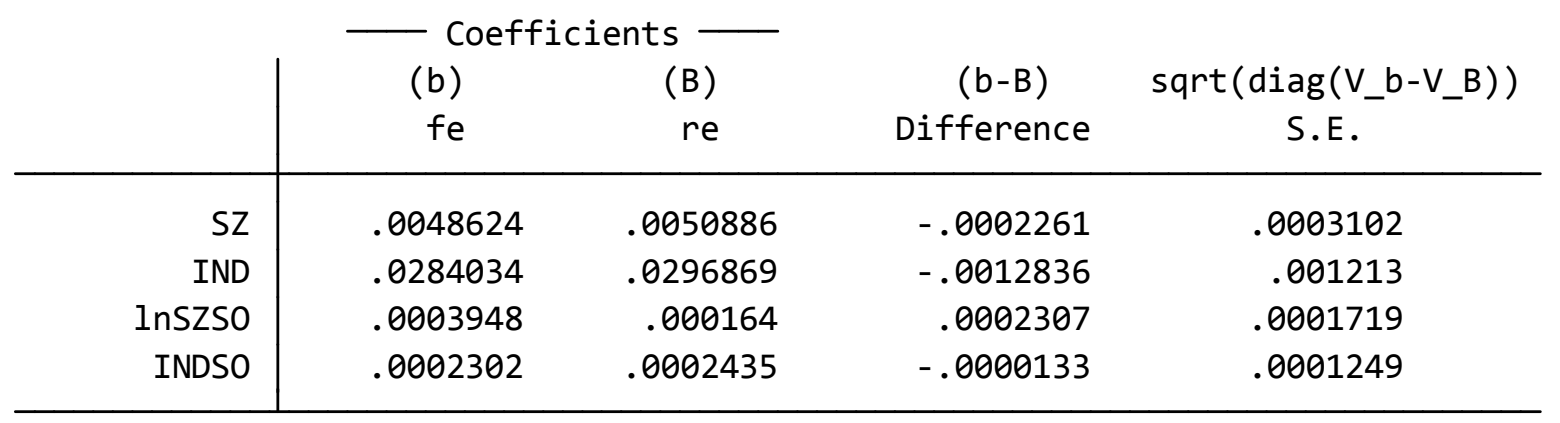

$\mathrm{b}=$ consistent under $\mathrm{Ho}$ and $\mathrm{Ha}$; obtained from xtreg $B=$ inconsistent under $\mathrm{Ha}$, efficient under $\mathrm{Ho}$; obtained from xtreg

Test: Ho: difference in coefficients not systematic

$$
\begin{aligned}
\operatorname{chi}(4) & = & (b-B) '\left[\left(V_{-} b-V_{-} B\right)^{\wedge}(-1)\right](b-B) \\
& = & 3.08 \\
\text { Prob }>\text { chi2 } & = & 0.5449
\end{aligned}
$$

- xtreg GEI SZ IND InSZSO INDSO, robust re

Random-effects GLS regression

Group variable: id

R-sq:

within $=0.0922$

between $=0.0824$

overall $=0.0716$

$\operatorname{corr}\left(u_{-} i, X\right)=\theta$ (assumed)
Number of obs $=480$

Number of groups $=54$

Obs per group:

$\begin{array}{rr}\min = & 2 \\ \operatorname{avg}= & 8.9 \\ \max = & 10\end{array}$

Wald chi2(4) $=4.09$

Prob $>$ chi2 $=0.3942$

(Std. Err. adjusted for 54 clusters in id)

\begin{tabular}{r|rlrrrr}
\hline & \multicolumn{7}{|c}{ Robust } \\
GEI & Coef. & Std. Err. & $z$ & $\mathrm{P}>|z|$ & {$[95 \%$ Conf. Interval] } \\
\hline SZ & .0050886 & .0028084 & 1.81 & 0.070 & -.0004158 & .010593 \\
IND & .0296869 & .0203033 & 1.46 & 0.144 & -.0101068 & .0694806 \\
InSZSO & .000164 & .0006056 & 0.27 & 0.787 & -.001023 & .001351 \\
INDSO & .0002435 & .0008844 & 0.28 & 0.783 & -.0014899 & .0019769 \\
_cons & -.0311481 & .0201028 & -1.55 & 0.121 & -.0705488 & .0082526 \\
\hline sigma_u & .02795161 & & & & \\
sigma_e & .01308046 & & & & \\
rho & .82034856 & (fraction of variance due to u_i) & \\
\hline
\end{tabular}


. reg GEI SZ IND InSZSO INDSO FS

\begin{tabular}{|c|c|c|c|c|c|c|}
\hline Source & SS & $d f$ & MS & Number of obs & $=$ & 480 \\
\hline Model & .066627864 & 5 & .013325573 & Prob > F & $=$ & 0.0000 \\
\hline Residual & .449118695 & 474 & .000947508 & R-squared & $=$ & 0.1292 \\
\hline Total & .51574656 & 479 & .001076715 & Root MSE & $=$ & $\begin{array}{l}.03200 \\
.03078\end{array}$ \\
\hline
\end{tabular}

\begin{tabular}{r|rrrrrr}
\hline GEI & Coef. & Std. Err. & $t$ & $\mathrm{P}\rangle|\mathrm{t}|$ & {$[95 \%$ Conf. Interval] } \\
\hline SZ & .0016293 & .0019002 & 0.86 & 0.392 & -.0021045 & .0053631 \\
IND & .0551114 & .0125275 & 4.40 & 0.000 & .030495 & .0797277 \\
InSZSO & -.0008128 & .0007173 & -1.13 & 0.258 & -.0022222 & .0005966 \\
INDSO & -.0001214 & .001043 & -0.12 & 0.907 & -.0021709 & .0019281 \\
FS & .008223 & .002004 & 4.10 & 0.000 & .0042852 & .0121608 \\
_cons & -.0826486 & .0125319 & -6.60 & 0.000 & -.01072736 & -.0580237 \\
\hline
\end{tabular}

. vif

\begin{tabular}{r|rr} 
Variable & VIF & $1 /$ VIF \\
\hline InSZSO & 1.89 & 0.529294 \\
FS & 1.78 & 0.562536 \\
INDSO & 1.75 & 0.570034 \\
SZ & 1.63 & 0.612075 \\
IND & 1.02 & 0.977040 \\
\hline Mean VIF & 1.62 &
\end{tabular}


- imtest, white

White's test for Ho: homoskedasticity

against $\mathrm{Ha}$ : unrestricted heteroskedasticity

$\operatorname{chi2}(20)=121.17$

Prob $>$ chi2 $=0.0000$

Cameron \& Trivedi's decomposition of IM-test

\begin{tabular}{r|rrc}
\hline Source & chi2 & df & p \\
\hline Heteroskedasticity & 121.17 & 20 & 0.0000 \\
Skewness & 88.00 & 5 & 0.0000 \\
Kurtosis & 28.75 & 1 & 0.0000 \\
\hline Total & 237.91 & 26 & 0.0000 \\
\hline
\end{tabular}

. ovtest

Ramsey RESET test using powers of the fitted values of GEI Ho: model has no omitted variables

$$
\begin{aligned}
F(3,471)= & 10.15 \\
\text { Prob }>F= & 0.0000
\end{aligned}
$$

- xtreg GEI SZ IND InSZSO INDSO FS

Random-effects GLS regression

Group variable: id

R-sq:

within $=0.1083$

between $=0.1166$

overall $=0.1090$

$\operatorname{corr}\left(u_{-} i, X\right)=0$ (assumed)
Number of obs $\quad=\quad 480$

Number of groups = 54

Obs per group:

$\begin{array}{rr}\min = & 2 \\ \operatorname{avg}= & 8.9 \\ \max = & 10\end{array}$

Wald $\operatorname{chi2}(5) \quad=\quad 57.99$

Prob > chi2 $=0.0000$

\begin{tabular}{r|rrrrrr}
\hline GEI & Coef. & Std. Err. & $z$ & $\mathrm{P}>|z|$ & [95\% Conf. Interval] \\
\hline SZ & .0039651 & .001195 & 3.32 & 0.001 & .0016229 & .0063072 \\
IND & .0273397 & .0072129 & 3.79 & 0.000 & .0132027 & .0414767 \\
InSZSO & .0002846 & .0005567 & 0.51 & 0.609 & -.0008064 & .0013757 \\
INDSO & .0002639 & .0006278 & 0.42 & 0.674 & -.0009665 & .0014943 \\
FS & .0093205 & .0028849 & 3.23 & 0.001 & .0036662 & .0149748 \\
_cons & -.0909543 & .0200734 & -4.53 & 0.000 & -.1302974 & -.0516111 \\
\hline sigma_u & .02771949 & & & & & \\
sigma_e & .01298005 & & & & \\
rho & .82016178 & (fraction of variance due to u_i) & \\
\hline
\end{tabular}


- xttesto

Breusch and Pagan Lagrangian multiplier test for random effects

$$
\begin{aligned}
& \mathrm{GEI}[\mathrm{id}, \mathrm{t}]=\mathrm{Xb}+\mathrm{u}[\mathrm{id}]+\mathrm{e}[\mathrm{id}, \mathrm{t}] \\
& \text { Estimated results: }
\end{aligned}
$$

\begin{tabular}{r|cc} 
& Var & sd $=\operatorname{sqrt}($ Var $)$ \\
\hline GEI & .0010767 & .0328133 \\
$\mathrm{e}$ & .0001685 & .0129801 \\
$\mathrm{u}$ & .0007684 & .0277195
\end{tabular}

Test: $\quad \operatorname{Var}(u)=0$

$$
\text { chibar2(01) }=1500.49
$$

Prob $>$ chibar $2=0.0000$

- xtreg GEI SZ IND InSZSO INDSO FS, fe

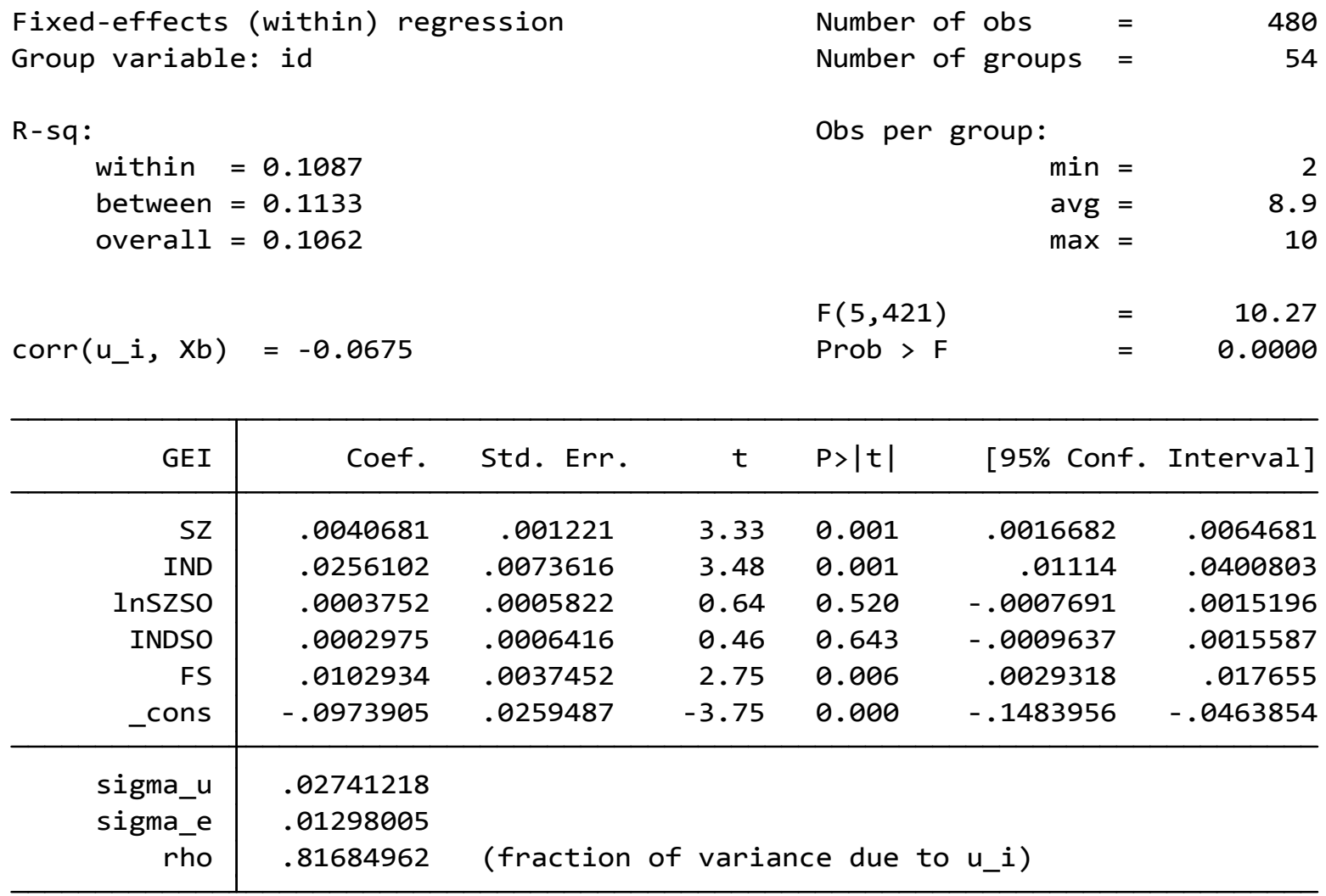

F test that all u_i=0: $F(53,421)=42.35$ 
. est store fe

- xtreg GEI SZ IND InSZSO INDSO FS, re

Random-effects GLS regression Group variable: id

R-sq:

within $=0.1083$

between $=0.1166$

overall $=0.1090$
Number of obs=

Number of groups =

480

54

Obs per group:

$\begin{array}{rr}\min = & 2 \\ \operatorname{avg}= & 8.9 \\ \max = & 10\end{array}$

Wald chi2(5)

$=$

57.99

$\operatorname{corr}\left(u_{-} i, X\right)=\theta$ (assumed)

Prob > chi2 $=0.0000$

\begin{tabular}{r|rlcrrr}
\hline GEI & Coef. & Std. Err. & z & P $>|z|$ & [95\% Conf. Interval] \\
\hline SZ & .0039651 & .001195 & 3.32 & 0.001 & .0016229 & .0063072 \\
IND & .0273397 & .0072129 & 3.79 & 0.000 & .0132027 & .0414767 \\
InSZSO & .0002846 & .0005567 & 0.51 & 0.609 & -.0008064 & .0013757 \\
INDSO & .0002639 & .0006278 & 0.42 & 0.674 & -.0009665 & .0014943 \\
FS & .0093205 & .0028849 & 3.23 & 0.001 & .0036662 & .0149748 \\
_cons & -.0909543 & .0200734 & -4.53 & 0.000 & -.1302974 & -.0516111 \\
\hline Sigma_u & .02771949 & & & & & \\
sigma_e & .01298005 & & & & \\
rho & .82016178 & (fraction of variance due to u_i) & \\
\hline
\end{tabular}


- est store re

- hausman fe re

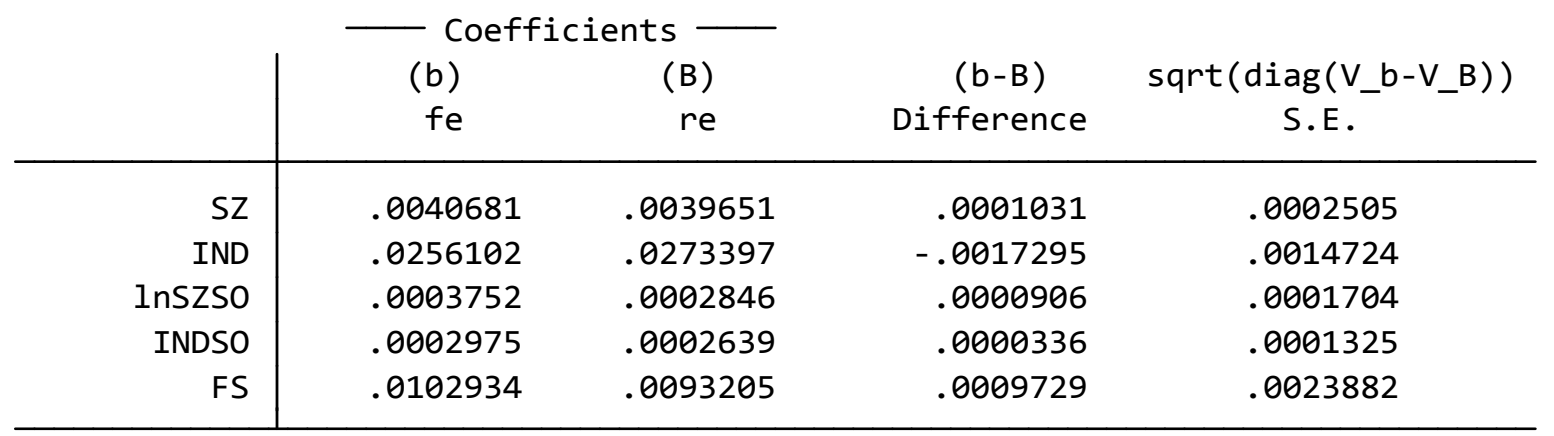

$\mathrm{b}=$ consistent under $\mathrm{Ho}$ and $\mathrm{Ha}$; obtained from xtreg $B=$ inconsistent under $\mathrm{Ha}$, efficient under Ho; obtained from xtreg

Test: Ho: difference in coefficients not systematic

$$
\begin{aligned}
\operatorname{chi2}(5) & = & (b-B) '\left[\left(V_{-} b-V_{-} B\right)^{\wedge}(-1)\right](b-B) \\
& = & 1.97 \\
\text { Prob }>\text { chi2 } & = & 0.8527
\end{aligned}
$$

- xtreg GEI SZ IND InSZSO INDSO FS, robust re

Random-effects GLS regression

Group variable: id

R-sq:

$$
\begin{aligned}
& \text { within }=0.1083 \\
& \text { between }=0.1166 \\
& \text { overall }=0.1090
\end{aligned}
$$

$\operatorname{corr}\left(u_{-} i, X\right)=0$ (assumed)

Number of obs $\quad=\quad 480$ Number of groups $=54$

Obs per group:

$$
\begin{array}{rlr}
\min & = & 2 \\
\operatorname{avg}= & 8.9 \\
\max & = & 10 \\
\text { Wald } \operatorname{chi2}(5) & & \\
& = & 8.39
\end{array}
$$$$
\text { Prob > chi2 }=0.1360
$$

(Std. Err. adjusted for 54 clusters in id)

\begin{tabular}{r|rrrrrr}
\hline & \multicolumn{7}{|c}{ Robust } \\
GEI & Coef. & Std. Err. & $z$ & $\mathrm{P}>|z|$ & {$[95 \%$ Conf. Interval] } \\
\hline SZ & .0039651 & .0029816 & 1.33 & 0.184 & -.0018788 & .0098089 \\
IND & .0273397 & .019653 & 1.39 & 0.164 & -.0111795 & .0658589 \\
InSZSO & .0002846 & .0005554 & 0.51 & 0.608 & -.000804 & .0013732 \\
INDSO & .0002639 & .000896 & 0.29 & 0.768 & -.0014922 & .00202 \\
FS & .0093205 & .0047221 & 1.97 & 0.048 & .0000654 & .0185756 \\
_cons & -.0909543 & .0384044 & -2.37 & 0.018 & -.062254 & -.0156831 \\
\hline sigma_u & .02771949 & & & & & \\
sigma_e & .01298005 & & & & \\
rho & .82016178 & (fraction of variance due to u_i) & \\
\hline
\end{tabular}


. xtserial GEI SZ IND

Wooldridge test for autocorrelation in panel data HO: no first order autocorrelation

$$
\begin{array}{rr}
F(1, \quad 57)= & 580.601 \\
\text { Prob }>F= & 0.0000
\end{array}
$$

- xtserial GEI SZ IND FS

Wooldridge test for autocorrelation in panel data HO: no first order autocorrelation

$$
\begin{array}{rr}
\mathrm{F}(\mathrm{1}, 57)= & 586.693 \\
\text { Prob }>\mathrm{F}= & 0.0000
\end{array}
$$

- xtserial GEI SZ IND InSZSO INDSO

Wooldridge test for autocorrelation in panel data HO: no first order autocorrelation

$$
\begin{array}{rr}
F(1,50)= & 178.422 \\
\text { Prob }>F= & 0.0000
\end{array}
$$

- xtserial GEI SZ IND InSZSO INDSO FS

Wooldridge test for autocorrelation in panel data HO: no first order autocorrelation

$$
\begin{array}{rrr}
\mathrm{F}(1,50) & = & 178.318 \\
\text { Prob }>\mathrm{F} & = & 0.0000
\end{array}
$$

- swilk GEI SZ IND SO FS

Shapiro-Wilk W test for normal data

\begin{tabular}{r|rcrrr} 
Variable & Obs & W & V & z & Prob $>$ Z \\
\hline GEI & 580 & 0.86602 & 51.528 & 9.539 & 0.00000 \\
SZ & 580 & 0.97153 & 10.949 & 5.791 & 0.00000 \\
IND & 580 & 0.89018 & 42.239 & 9.058 & 0.00000 \\
SO & 580 & 0.44033 & 215.252 & 12.999 & 0.00000 \\
FS & 580 & 0.98426 & 6.054 & 4.357 & 0.00001
\end{tabular}

